\title{
How OFDI Promotes High-Technology Multinationals' Innovation: From the Perspective of a Cross-Border Business Model
}

\author{
Deping Xiong ${ }^{1}$, Mengyuan Yang ${ }^{1}$, Qian Chen ${ }^{2, *}$, Yilei Sun ${ }^{1, *}$, Giuseppe Cillo ${ }^{3}$, Antonio Usai ${ }^{4}$ (D) \\ and Xiang Wang 5
}

check for updates

Citation: Xiong, D.; Yang, M.; Chen, Q.; Sun, Y.; Cillo, G.; Usai, A.; Wang, $X$. How OFDI Promotes

High-Technology Multinationals' Innovation: From the Perspective of a Cross-Border Business Model. Sustainability 2022, 14, 1417 https://doi.org/10.3390/su14031417 Academic Editor: Ioannis Nikolaou

Received: 14 December 2021

Accepted: 24 January 2022

Published: 26 January 2022

Publisher's Note: MDPI stays neutral with regard to jurisdictional claims in published maps and institutional affiliations.

Copyright: (C) 2022 by the authors. Licensee MDPI, Basel, Switzerland. This article is an open access article distributed under the terms and conditions of the Creative Commons Attribution (CC BY) license (https:// creativecommons.org/licenses/by/ $4.0 /)$.
1 School of Finance, Yunnan University of Finance and Economics, Kunming 650500, China; xiongdeping@nbu.edu.cn (D.X.); yangmengyuan@ynufe.edu.cn (M.Y.)

2 School of Intellectual Property, Nanjing University of Science and Technology, Nanjing 210094, China

3 Department of Agronomy, Animals, Food, Natural Resources and Environment (DAFNE), University of Padova, Viale dell'Università, 16, 35020 Legnaro, Italy; giuseppe.cillo@studenti.unipd.it

4 Department of Economics and Business, University of Sassari, 07100 Sassari, Italy; ausai@uniss.it

5 Yunnan College of Tourism Vocation, Kunming 650500, China; wx215@sina.com

* Correspondence: chenqianmickey@njust.edu.cn (Q.C.); sunyilei01@stu.ynufe.edu.cn (Y.S.)

\begin{abstract}
High-quality innovation in cross-border business models is the focus of innovative development. However, some enterprises are blindly obsessed with focusing on the quantity of innovation, while they neglect the quality of innovation. As a result, the quantity of innovation in cross-border business models is not proportional to the quality, and cross-border business models need continuous improvement. High-quality innovation in cross-border business models is also related to outward foreign direct investment (OFDI) and knowledge absorptive capacity. The purpose of this study is to explore the relationship between OFDI and innovation quality in cross-border business models. This study proposes that knowledge absorptive capacity plays a mediating transmission role between OFDI and innovation quality. Based on panel data for 478 Chinese high-tech multinational enterprises in the period from 2014 to 2019, the paper uses moderated path analysis to construct a non-linear mediated transmission model of knowledge absorptive capacity in terms of the OFDI and innovation quality of high-tech enterprises. The results show that there is an inverted U-shaped relationship between OFDI and innovation quality. Knowledge absorptive capacity plays an inverted U-shaped mediating role in the transmission between OFDI and innovation quality. In a post hoc analysis, it was found that a low degree of OFDI has an inverted U-shaped relationship with innovation quality, and a high degree of OFDI negatively inhibits innovation quality. Therefore, Chinese high-tech enterprises operating cross-border must maintain an appropriate level of OFDI by improving the matching mechanism between OFDI and knowledge absorptive capacity, which is conducive to improving the innovation quality of multinational enterprises in host countries.
\end{abstract}

Keywords: cross-border business model; outward foreign direct investment; knowledge absorptive capacity; innovation quality; high-technology enterprises

\section{Introduction}

In 2017, the report of the 19th National Congress of the Communist Party of China pointed out that "innovation is the first driving force for development". With the further development of innovation, Chinese enterprises have increased their outward foreign direct investment (OFDI), resulting in the development trend of large-scale "going out". Thus, cross-border commerce has become the mainstream of development for the innovation era. According to the National Bureau of Statistics, by the end of 2018, China's outward foreign direct investment (OFDI) increased significantly to $\$ 120.5$ billion, which was up 8.9 percent year on year. However, the results of outward foreign direct investment (OFDI) by Chinese 
enterprises are not satisfactory. In recent years, the average income of Chinese enterprises from outward foreign direct investment has only been $3.3 \%$, which is much lower than the $22 \%$ income spread of FDI in China in the same period. According to a 2013 report by PWC, the success rate of overseas mergers and acquisitions by Chinese enterprises was only $40 \%$, which resulted in a huge waste of domestic resources. At present, Chinese enterprises are in the exploratory stage of transnational development in which the high-tech industry, with its contemporary cutting-edge knowledge and strong penetration into other industries, is the main carrier of innovation and development at this stage. However, except for a few fields, such as the quantum communications industry, there is still a large gap between most of China's high technology industry and the professional level of developed countries. The Central Working Conference pointed out that the lack of innovation efficiency and quality in Chinese enterprises will lead to various problems of uncoordinated and unbalanced development. Therefore, high-quality innovation in cross-border business models will be the focus of future economic development.

However, during the development of cross-border business, some Chinese enterprises are blindly obsessed with expanding the scale of their enterprises and focusing on the quantity of innovation, while they neglect the quality of innovation [1], which creates a negative impression of Chinese enterprises, such as destructive investment, counterfeit and shoddy products, environmental damage, and copycatting (Voss, 2008) [2]. Thus, the strategic deployment of enterprises, with a focus on the rational allocation of innovation resources, is crucial to the high-quality development of Chinese OFDI. Currently, academic views on Chinese OFDI and innovation are mixed. Some scholars believe that China's OFDI will suppress the level of domestic investment and reduce the level of domestic technological innovation while overseas investment will easily take up domestic innovation resources, reduce the ability to absorb and transform knowledge, and inhibit the improvement of innovation efficiency $[3,4]$. Other scholars hold the opposite view, that OFDI can produce an innovation spillover effect to improve technological levels and promote innovation performance while OFDI facilitates the stimulation of innovation consciousness and improves R\&D levels for high-speed development (Jordan, 1998) [5]. The above view has certain limitations. In addition, some scholars believe that internal factors and external conditions will have an impact on the spillover effect of OFDI innovation in China, which must be analyzed comprehensively, and there may be a complex non-linear relationship. As China is still in the process of developing innovation, a parent company's prediction of the situation in the host country may be biased at any time, and it is risky to blindly judge the advantages and disadvantages of OFDI and the innovation of Chinese enterprises. Therefore, the focus of high-quality development in cross-border business models is to identify the complex relationship between the OFDI and innovation quality of Chinese high-tech enterprises.

In addition to increasing innovation investment to improve success rate, Chinese enterprises must strengthen their knowledge absorptive capacity if they want to be protected from the challenges of the host market in international trade cooperation. Then, host country policies, cultures, markets, education, and resources will have a significant impact on business operations. Further, to improve the success rate of Chinese outward investment, knowledge absorptive capacity is of great significance to firms in distress (Lichtenthaler, 2011) [6]. Efficient absorption is an important process for improving resource utilization and enhancing innovation spillovers, and it is an effective way for multinational enterprises to strengthen their understanding of host country needs. Enhancing knowledge absorption requires firms to break through barriers, to identify, acquire, and integrate key information promptly in response to market developments (Nonaka, 2006) [7]. Thus, the improvement of innovation quality to a large extent depends on the ability of firms to effectively absorb and utilize innovation spillovers from host countries, and the roles of innovation inputs and knowledge absorptive capacity are not separate or opposed to each other for high-quality development. Knowledge management theory suggests that a firm's absorptive capacity determines its developmental level and that a mismatch between resources and capacity 
leads to asymmetric information identification, resulting in different resource innovation effects and unnecessary costs and expenses (Bourgeois, 1981) [8]. Therefore, different levels of OFDI by Chinese high-tech enterprises may affect the knowledge absorptive capacity and innovation spillovers of multinational enterprises, and firms can enhance their knowledge absorptive capacity and further improve the quality of innovation through innovation strategies.

In the cross-border business model, is it better for Chinese high-tech enterprises to invest more or less in OFDI, and what level of investment can effectively promote high-quality cross-border development? What is the complex relationship between OFDI and innovation quality for Chinese enterprises? In the face of knowledge absorptive capacity, how can multinational enterprises develop investment strategies abroad that match their knowledge absorptive capacity and thereby enhance the quality of innovation? What role does knowledge absorptive capacity play in the relationship between OFDI and innovation quality in high-tech enterprises in China? To analyze these issues, we propose a relational model of innovation quality driven by OFDI through the non-linear mediated transmission of knowledge absorptive capacity in Chinese high-tech enterprises based on innovation management theory, quality management theory, resource base theory, and knowledge management theory. Further, exploring the development path of OFDI, knowledge absorptive capacity, and innovation quality of multinational enterprises is of great significance for the future development of the Chinese cross-border business model.

\section{Theory and Hypotheses}

\subsection{Outward Foreign Direct Investment}

1. The difference between the OFDI of developing and developed countries.

Currently, there are large differences in the investment behavior of firms in developing and developed countries (Bernard, 2009) [3]. For OFDI in developed countries, OFDI by developed country multinationals has two characteristics: First, it has proprietary assets and emphasizes the special assets that should be owned by multinationals (Hymer, 1970; Fan, 2018) $[9,10]$; compared to host country firms, multinational firms are unfamiliar with local policies, cultures, and economic environments, and to gain a competitive advantage, they must have proprietary assets in terms of innovation, costs, personnel, and marketing to compensate for competitive disadvantages (Voss, 2008) [2]. Second, multinational firms require internalization models, to gain more efficient coordination within developed country firms so that their multinational subsidiaries and parent companies are under the same governance structure (Caves, 1971; Bailey, 2017) [11,12]. Rugman (2007) argues that mature multinational enterprises have internal trading systems that compensate for external market failures or gaps and that internalization models do not allow firms to avoid the host market but to move the boundaries between firms and the market through agreements instead of market transactions [13]. Both proprietary assets and internalization models facilitate the allocation of resources to investment behavior by developed country firms (Asumadu, 2020) [14]. Concerning OFDI in developing countries, developing country multinational enterprises are smaller and less mature than their developed counterparts (Desbordes, 2017; Isaksson, 2018) [15,16]. Thus, there is controversy in academic circles about the development of multinational enterprises in developing countries, and some scholars believe that proprietary assets and internalization models are not suitable for developing country enterprises, that developing country enterprises started late and have greater growth potential, and that they must find new development concepts according to their peculiarities (Juran, 1992) [17]. Another group of scholars has argued that the requirements of multinational enterprises were essentially the same and that developing countries could continue to operate in the mainstream. In developing countries, small multinational enterprises are more flexible because of their smaller scales and simpler technology, so they easily obtain recognition and acceptance in the host market (Dhahri, 2020) [18]. In developed countries, because of the large difference between the higher technological levels and local development, it is difficult to realize localization transformation 
and low environmental adaptability (Wells, 1983; Sarkodie, 2019) [19,20], and it is easy to increase the operating difficulty of multinational enterprises. Wiklund (2008) argues that developing country firms have an advantage over developed country firms for OFDI because developing country parent companies have adapted to imperfect policy regimes and are better able to deal with the constraints of opaque rules in host countries [21].

2. The analysis of Chinese enterprises' OFDI.

With the further promotion of innovation development, as the largest developing country, China has seen a year-on-year increase in outward foreign direct investment, which is bound to attract global attention (Fan, 2018, Isaksson, 2018) [10,16]. Currently, academics mainly analyze China's OFDI from macro and micro perspectives. From the macro perspective, Rugman and Li (2007) and Deng (2009) analyze the motives of OFDI mainly in terms of Chinese OFDI motives, and they note that OFDI motives are conducive to a mutual win-win situation between China and host countries and will accelerate globalization [13,22]. Wang (2008) focuses on the economic and institutional support behind the development of OFDI in China and finds that the ability to obtain funds in imperfect capital markets at interest rates below market equilibrium can be a facilitating factor for OFDI [23]. Many other scholars have analyzed the factors that influence the location of OFDI in China (Zhang, 2016; Liu, 2019) [24,25]. From a micro perspective, Cheng (2010) analyzes the success and failure factors and success or failure rates of Chinese enterprises' overseas acquisitions using data from cases of Chinese enterprises' overseas acquisitions in the process of "going out" [26]. Wang (2012) analyzes the factors influencing the OFDI of Chinese enterprises during 2006-2007 using the Database of Chinese Industrial Enterprises [4]. Other scholars have examined the degree of influence of firms' foreign direct investment decisions in terms of internalized advantages and proprietary assets (Thomas, 2020; Bezuidenhout, 2018) [27,28]. It has been shown that firms with higher innovation efficiency have higher internalization advantages and proprietary assets, with innovation efficiency representing inputs and outputs, internalization advantages indicating higher internal governance efficiency than the market level, and proprietary asset advantages being monopoly assets acquired by the product in the market (Wang, 2012; Lichtenthaler, 2011; Sarkodie, 2019) $[4,6,20]$. Therefore, to further analyze the influence of internalization advantages and proprietary assets on the path of high-quality OFDI development of Chinese enterprises, we focus on high technology industries that are permeable to other industries based on the List of Enterprises (Institutions) with Foreign Investment. This paper conducts a comprehensive analysis of the factors influencing the high-quality development of OFDI, taking the theory of multinational enterprises, the theory of OFDI in developing countries, and Chinese innovation development as the background. Among the internalized advantages, we select knowledge absorptive capacity, firm size, overseas R\&D breadth, and overseas R\&D depth, which have a greater impact on the sustainable development of high-tech enterprises. Among the proprietary assets, we select for analysis, OFDI and firm performance.

\subsection{Innovation Quality of High-Tech Enterprises}

With the further promotion of Chinese companies' transnational operations, some companies ignore their responsibilities and obligations and pursue price wars, scale, and low costs to solidify the low-end, cheap image of Chinese brands and the concept of madein-China in the minds of foreign consumers. Meanwhile, some oil and mining companies have been wound up in Mexico, Indonesia, and Mongolia for damaging the local environment (Bloom, 2007) [29]. Therefore, the quality of innovation is crucial for a mutually beneficial and cooperative development path for both multinational enterprises and host countries. High-tech industries are characterized by high knowledge, high innovation, and strong penetration to other industries, and they are the leading industries for the high-quality development of Chinese enterprises. Currently, the academic research on innovation quality in high-tech enterprises focuses on the concept and its link to innovation performance. Innovation quality is an important concept in the field of quality management 
and innovation management, which has evolved from "quality management" to "innovative quality". In the beginning, the basis of quality management was only to ensure whether the product quality met specifications, and it gradually added process and customer perspectives to form total quality management with multiple quality standards (Manova, 2008; $\mathrm{Li}, 2016)[30,31]$. Quality management was later defined from the perspective of innovation management. Haner was the first to introduce the concept of innovation quality, which he defined as the integrated innovation performance in the three areas of product and service quality, actual process quality, and high-level business quality (Haner, 2002) [1]. Innovation quality is based on continuous improvement based on quality innovation, which is quality improvement and performance enhancement under existing boundary conditions. while innovation quality is a systematic process with dynamic characteristics, it is the sum of innovation performance in all areas of the firm (Deng, 2010) [22]. From an industrial perspective, Nocke (2007) proposes that the quality of innovation is essentially a synergistic development within and outside the industry, emphasizing industrial adaptability and an organization's comprehensive enhancement of innovation within each domain [32]. In this paper, we hold that innovation quality is to ensure the quality development of design, manufacturing, sales, service, and other links, as well as the comprehensive innovation performance of enterprises.

The research on the correlation between innovation quality and innovation performance mainly focuses on the differences and connections between them. In terms of distinction, innovation performance emphasizes the profitability of enterprises (Chesbrough, 2006) [33], which is usually expressed in terms of new technology profitability, market share, and revenue from new product sales. However, the constant emphasis on innovation performance can have a negative impact, and, by the end of 2018, the number of investment dispute arbitration cases against host countries worldwide reached 942, an increase of $60.47 \%$ year-on-year, mostly due to significant environmental damage, disruptive investments, and social risks resulting from companies' pursuit of economic efficiency (Wells, 1983; Liu, 2019; Cheng, 2010) [19,25,26]. However, the quality of innovation emphasizes a firm's comprehensive capabilities, including operations, services, profitability, and innovation, as a means of achieving breakthroughs in each area (Conconi, 2016) [34]. Improving the quality of innovation can effectively protect the legitimate rights and interests of Chinese enterprises "going out" and effectively reduce the probability of China's investment disputes in neighboring countries (Daniel, 2004; West, 2006) [35,36]. Many scholars use the ratio of patents to patent applications to measure the quality of innovation because the patent grant rate can better reflect the operation, management, profitability, and innovation capabilities of enterprises (Hsu, 2015) [37]. In terms of the correlation between them, innovation performance is the basis of innovation quality and plays an important role in promoting changes in innovation quality. Innovation performance change is the premise and preparation for innovation quality change, and innovation quality change is the inevitable result of innovation performance change, which influences each other. Chesbrough (2006) found that low innovation performance decreases trust and business strength and inhibits high-quality development, and innovation performance can provide resource security for high-quality development and increase risk exploration capital [33].

\subsection{OFDI and Innovation Quality of Chinese High-Tech Enterprises}

The innovation driver for Chinese OFDI comes from two sources: the number of resource reserves and the awareness and motivation to innovate. An innovation strategy will not be implemented when a company's resources are not aligned with its innovation goals and it is not aware of the need for innovation [37-40]. With the further advancement of the Belt and Road Initiative, the trend of Chinese enterprises in "going out" has become increasingly strong while investment in countries along the route has increased gradually. Innovation management theory argues that investment behavior increases profit opportunities and contributes to the implementation of quality development strategies (Hymer, 1970) [9]. On the one hand, investment is mainly the use of liquid cash and assets to 
invest in the host country to obtain profits, reflecting the existing resources and innovation capacity of enterprises. The considerable amount of investment in such cases can enhance the host country's trust in Chinese enterprises to invest, give corresponding support in terms of policy and environment, attract local talent to join, enhance the adaptability of the enterprise environment, reduce investment disputes, and drive the improvement of innovation quality (Pradhan, 2011; Zahra, 2002) [41,42]. On the other hand, there are still imperfections in the Chinese market system compared to those of developed countries. Thus, Chinese enterprises have adapted to the imperfect market system and have a clear advantage in dealing with the opaque policies of host countries and adapting to the development policies of host country markets, and managers have a higher ability to cope with market prediction and identify potential innovation opportunities (Hsu, 2015) [37]. At the same time, the technology gap between Chinese high-tech enterprises and countries along the "Belt and Road" is not very wide, which makes it easy for them to integrate into the host market and enhance the efficiency of technology transfer and promote high-quality development (Zahra, 2002) [41]. Outward foreign direct investment by Chinese enterprises requires the establishment of relevant $R \& D$ and production institutions in the host country to carry out investment matching work, which will inevitably integrate the relevant culture and technology of the host country, resulting in an innovation spillover effect and making it easier for enterprises to enhance their independent innovation capacity by combining the technological advantages of the host country.

However, as China's high-tech enterprises are pushing forward with OFDI, some scholars say that it is risky for companies to devote resources to unknown projects on a large scale. With the increasing amount of investment, the implementation of localization strategies of multinational enterprises is more mature. The outward investment behavior of enterprises cannot avoid the possible competitive risks, such as imitation by external competitors and independent portals for internal personnel, which may generate risks, such as disclosure of innovative content, thus inhibiting the good development trend of enterprises and generating an innovation crisis (Harford, 1999) [43]. At the same time, over-investment by high-tech enterprises overseas can also lead to weakened innovation opportunities for the parent company. As the international situation is volatile and the host country's environment can change at any time, over-investment by high-tech enterprises overseas can reduce overall market sensitivity and vigilance (Nohria, 1996) [44]. Blind investment by multinational enterprises can also increase information asymmetries with host countries due to cultural, religious, and customary differences, weakening innovation and motivation. Although OFDI will increase the venture capital of enterprises, when multinational enterprises engage in high investment behavior, large-scale capital outflows from abroad can force enterprises to be in a high-pressure environment, and their risktaking increases. Deangelo (2011) argues that blind investment by enterprises can weaken trust in the network of external relationships while strengthening creditor discipline and oversight, weakening incentives to innovate, and reducing managers room to innovate on their own [38]. A high level of investment tends to force enterprises to have complex financing relationships with suppliers and managers in the external market. Complex relationship networks tend to interfere with managerial decisions and weaken the perception of the host country's local business philosophy, which will enhance cross-cultural, cross-ethnic, and cross-values communication barriers between the two parties. Meanwhile, complex relationship networks tend to weaken the firm's ability to identify external innovation opportunities, further resulting in lower resource utilization and a significant reduction in innovation efficiency and quality (Liu,2011) [45]. Therefore, this paper posits the following hypothesis:

Hypothesis 1 (H1). There is an inverted $U$-shaped relationship between OFDI and the innovation quality of Chinese high-tech enterprises. A low degree of OFDI will promote innovation qual-ity, while a high degree of OFDI will inhibit innovation quality, and there is an optimal balance point. 


\subsection{OFDI, Knowledge Absorptive Capacity and Innovation Quality}

\section{OFDI and knowledge absorptive capacity}

Knowledge absorptive capacity is an important part of knowledge management theory (Smith, 2005) [46]. Cohen and Levinthal indicate that knowledge absorptive capacity, which is an enterprise's ability to acquire, learn and imitate external knowledge and technology, is central to innovation management [47]. Knowledge absorptive capacity should match enterprise resource storage and strategic development, and enterprises must improve their absorptive capacity phase-by-phase to improve the quality of innovation (Lichtenthaler, 2011; Scott, 2003) [6,48]. The sustainable development of enterprises is inseparable from the knowledge absorptive capacity. Due to the differences between the host country's market policy and the Chinese market, there are potential differences in technological levels. Against this background, managers must effectively identify, learn, digest and deploy based on their innovative strength, combined with host country market characteristics and development trends, to improve capital conversion and utilization and promote high-quality development. Heterogeneous knowledge resources in the host country have innovation spillover effects on the development of multinational enterprises, and available liquidity can facilitate the search for and identification of new knowledge. This can increase the training of skilled employees, promote the implementation of localization strategies, and help stimulate internal R\&D motivation, thereby enhancing overall absorptive capacity (Romer, 1990; Park, 2008) [49,50]. Working capital can improve the culture of multinational firms and support the development of innovative activities, which can increase the knowledge base and development of enterprises, and improve the efficiency of knowledge absorption (Thomas, 2020; Amore, 2013) [27,51]. OFDI by multinational enterprises can enhance managers' willingness to innovate and engage in risk-taking and risk-exploring capital, which can facilitate enterprises to be fully acquainted with the host country's policies, culture, technology, and other aspects. OFDI can help enterprises to actively formulate innovation strategies while the enterprises can identify and interpret information more effectively, which is conducive to the enhancement of knowledge absorptive capacity.

At the beginning of the investment period, multinational enterprises' positioning in the host market is vague, and the amount of investment is relatively limited. To strengthen their market position and enhance the recognition and acceptance of the host government, enterprises will develop a sense of innovation and motivation to be more sensitive and insightful in identifying external innovation opportunities (Zhang, 2013) [52]. Enterprises will increase the urgency of innovation, supply capital efficiently, and improve resource efficiency, and they can use the host country's development channels to overcome technical difficulties, narrow the differences between the two sides and increase the success rate of investment. At the low degree of investment stage, where external disruptions and risks are relatively high, enterprises gradually increase their absorptive capacity to ensure internal and external information symmetry between themselves and the host country to ensure the basic operations and returns of the multinational. The low investment activity indicates that companies will strengthen their infrastructure, improve capital utilization, and enable organizations to efficiently absorb diverse information. As multinational investment continues to advance, the perception of market ambiguity in the host country decreases while external market disruptions decrease, thus increasing the accuracy of strategic positioning of multinational enterprises. Meanwhile, corporate capital flows can be efficiently self-replenishing and allocated to innovative activities, implementing a talent localization strategy to ensure absorption efficiency (Foster, 2012) and reduce resource depletion [53]. When multinational enterprises invest excessively, higher cash flows can provide a financial cushion and support to cope with shocks in the host country's external environment. However, a good development posture can interfere with managers' decisions (James, 2005) [54]. Innovative strategies will also be weakened, and sensitivity to the external environment will be reduced. A low degree of investment will be made in the recruitment and training of locally skilled employees and the development of innovative activities. The knowledge 
gap between the two sides will increase, and the host government will easily question and reject the improper management of Chinese enterprises, resulting in reduced absorptive capacity (Zhong, 2015) [55]. Excessive liquidity can cause companies to ignore operational risks, reduce sensitivity and insight into the market environment and competitors, which can lead to blind innovation and increased losses (Ren, 2010) [56]. Enterprises also generate disruptive investments, increasing the risk of weakened knowledge absorptive capacity, and reducing the host government's trust in Chinese enterprise investment. Based on the above analysis, the paper proposes the following hypothesis.

Hypothesis 2 (H2). There is an inverted U-shaped relationship between OFDI and the knowledge absorptive capacity of Chinese high-tech enterprises. A low degree of OFDI will promote the knowledge absorptive capacity, while a high degree of OFDI will inhibit the knowledge absorptive capacity, and there is an optimal balance point.

\section{The non-linear mediating effect of knowledge absorptive capacity}

Knowledge absorptive capacity has a greater impact on the improvement of OFDI and the innovation quality of Chinese high-tech enterprises. The use of working capital by high-tech enterprises for investment and cooperation with host countries in research and development can help enterprises absorb technology and talent, further generating knowledge spillovers, thus compensating for the development disadvantages of both sides and promoting joint development, which has important implications for the creation and application of new knowledge and technology (Smith, 2005; Hansen, 2000) [46,57]. Circulating capital can support the operation of the business absorption process. Knowledge absorptive capacity is conducive to improving the efficiency of capital development and utilization, effectively reducing costs and consumption, matching external market information with firm information, helping enterprises gain stakeholder recognition and support, and improving the longevity and stability of innovation strategies. The improvement of innovation quality of high-tech enterprises depends on the attention of managers to knowledge absorption ability and whether to adopt the corresponding development mode of foreign investment. Cohen (2002) found that the failure of high-quality development is due to the failure of managers to reasonably match absorptive capacity according to the enterprise's resource reserves and market development characteristics, resulting in information asymmetry, which leads to a large difference between actual capacity and innovative capacity [58]. Knowledge absorptive capacity provides rich information channels for high-quality development, promotes internal and external knowledge flow, and is conducive to managers' deployment of working capital and exploratory innovation (Hall, 2015) [59]. Based on this, this paper argues that there is a non-linear mediating mechanism between OFDI and innovation quality in Chinese high-tech firms.

As multinational enterprises continue to grow, the unconstrained and easily deployable nature of liquidity will promote autonomous innovation and reduce dependence on external markets, organizational learning and imitation will enhance absorptive capacity, and high absorptive capacity will be more conducive to exploratory innovation and quality development [55-60]. High knowledge absorption can effectively reduce irrational optimistic decision-making by managers, enhance sensitivity to the external environment, and promote innovative development (Redding, 2004) [61]. Enterprises with low levels of investment behavior have a smooth knowledge absorption capacity because they have less ability to raise capital and take on less stress, and they will focus on the management required for basic operations. Under low investment behavior, corporate assets are more dedicated, and managers can maintain insight and sensitivity with limited liquidity and a network of financing relationships (Yoo, 2010; Teece, 2018) [62,63]. Enterprises can use these funds to establish a good relationship of supply and demand and cooperation and trust between multinational enterprises and host governments to reduce the knowledge gap between the two sides, to improve their business operations, to enhance their ability to absorb and apply knowledge, and to promote high-quality development. As investment 
behavior advances, higher levels of investment can unbalance a firm's financial leverage, weaken its knowledge absorption capacity, and inhibit its innovation capability. At present, the development of China's high-tech industry is beginning to take shape, and the operating risks of companies with a large number of financing relationships will be greater (Edwards, 2007) [64]. Multinational enterprises with high investment behavior have a complex network of relationships with host countries, and excessive implementation of localization strategies may lead to negative impacts, such as a crisis of trust. For example, India has refused to accept large-scale investments from telecommunications companies, such as China's Huawei and ZTE, because large-scale foreign investments would leak state secrets $[6,17,28]$. Such high investment behavior leads to an increase in knowledge ambiguity and complexity and a decrease in absorption efficiency due to environmental compounding and heterogeneity. In addition, over-investment may lead to an imbalance in the distribution of resources and funds between the parent company and its overseas subsidiaries, thus affecting the subjective consciousness of employees and making them prone to inertia or negative psychology, which is not conducive to the development of innovative activities, further weakening learning and absorption capabilities, and generating investment disputes and social risks. Based on the above analysis, the paper proposes the following hypothesis.

Hypothesis 3 (H3). Knowledge absorptive capacity has a mediating effect in the relationship between OFDI and innovation quality of Chinese high-tech enterprises. OFDI influences knowledge absorptive capacity and innovation quality through an inverted $U$-shaped curve effect, contributing to an inverted $U$-shaped relationship between OFDI and innovation quality.

Based on the above analysis, this paper builds a research model for innovation quality improvement driven by outward foreign direct investment in Chinese high-tech enterprises, as shown in Figure 1.

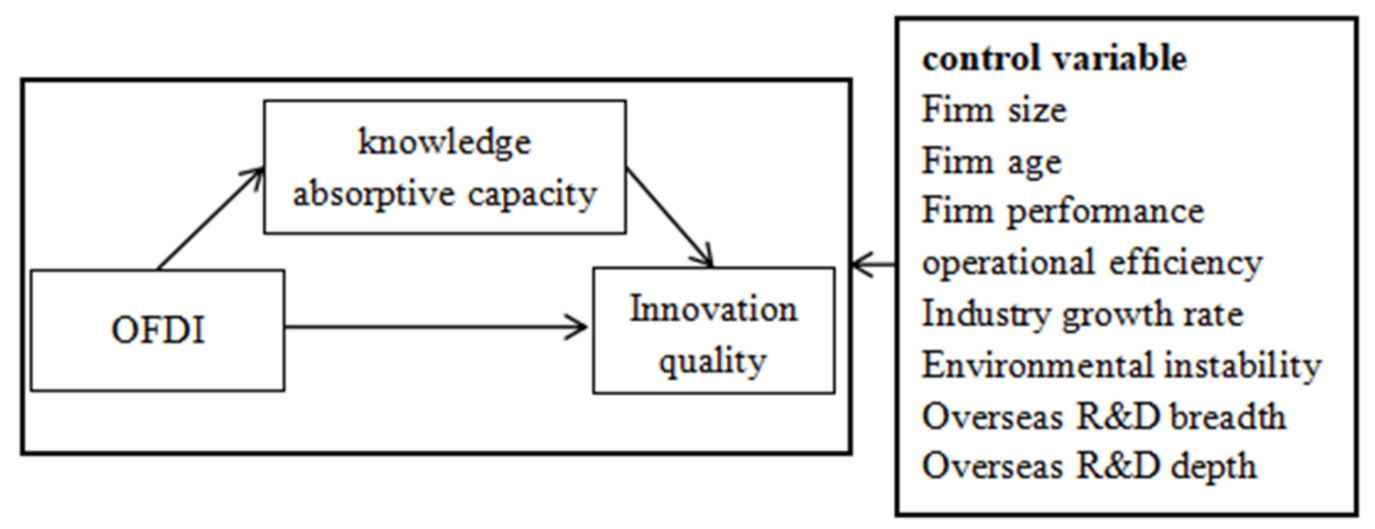

Figure 1. OFDI, knowledge absorptive capacity and innovation quality of high-tech enterprises.

\section{Data and Methods}

\subsection{Sample}

In recent years, Chinese high-technology enterprises have increased their investments in neighboring developing countries. Against the background of the development of Chinese OFDI, we focus mainly on the quality of innovation of Chinese multinational enterprises in neighboring countries. These neighboring countries are mainly divided into six regions: South-East Asia, South Asia, Central Asia, West Asia, and North Africa (the Middle East), Central and Eastern Europe, and Mongolia and Russia, with a total of 64 countries. Due to certain differences in resources, environment, culture, science and technology, education, and economic development among the participating countries, the proportion of direct investment by China's high-tech enterprises in neighboring countries varies. Chinese enterprises' investment in Southeast Asia is mainly concentrated in the 
fields of electricity, minerals, and medical care, while their investment in Central Asia is mainly concentrated in the fields of electronics and communications, and chemicals. Chinese enterprises' investments in South Asia, West Asia, and North Africa (Middle East) mainly focus on machinery manufacturing, energy exploration, and infrastructure construction. In Central and Eastern Europe, it mainly focuses on electronic communications, electrical appliances, and automobiles. In Mongolia and Russia investment mainly focuses on mineral development, construction, and building materials.

To ensure the validity of the innovation data, the data in this paper are based on the List of Enterprises (Institutions) Investing Abroad provided by the Ministry of Commerce of China and the Statistical Bulletin of China's Outward Foreign Direct Investment. The List of Enterprises (Institutions) Investing Abroad can be used to indicate which Chinese enterprises are making outbound investments, but only in existing outbound investment projects, excluding projects in which investments were made but have been terminated. The Statistical Bulletin of China's Outward Foreign Direct Investment is currently the most authoritative source of data on China's outward foreign direct investment, covering the overall outward foreign direct investment of enterprises, and it can be used to verify the accuracy of the List of Enterprises (Institutions) Investing Abroad. According to the 2002 OECD standards of China's National Bureau of Statistics, the high-tech industry (manufacturing) sector can be divided into six major industries including pharmaceutical manufacturing, aerospace, electronics and communication equipment, medical equipment and instrumentation manufacturing, computer and office equipment, and information chemicals. Using the OECD high-tech industry standards, we first matched, merged, and screened a total of 876 high-tech enterprises from 64 countries from the List of Enterprises (Institutions) Investing Abroad and the Statistical Bulletin of China's Outward Foreign Direct Investment.

Since the Statistical Bulletin of China's Outward Foreign Direct Investment (OFDI) provides only aggregated data at the national level and the industry level, and the data are not broken down to the enterprise level, it is not suitable for conducting a firm-level study of Chinese OFDI. Thus, we needed to sort out the details of OFDI behavior based on the 876 high-technology enterprise codes and then to remove the missing data and duplicate names from the WIND database and the Jiangsu Intellectual Property Think Tank Alliance. Since the Chinese government proposed the Belt and Road Initiative in 2013, cross-border business models became prevalent, to ensure the relevance of OFDI by Chinese enterprises in the context of the Belt and Road, we selected the data of high-tech enterprises from 2014 to 2019. The data of 478 high-tech multinational enterprises met the sample requirements and the actual final sample involved 3346 observations. In the end, we excluded some outliers, leaving a total of 2868 observations.

\subsection{Variables and Definitions}

Based on the relevant research of domestic and foreign scholars, OFDI, knowledge absorptive capacity, and innovation quality are defined as follows.

OFDI. Outward foreign direct investment by multinational enterprises is a way to combine the upstream resources of the enterprises with those resources of the downstream host country to maximize benefits (Bernard, 2009) [3]. Therefore, we follow the relevant study of Deng (2010) to quantitatively measure the intensity of the firm's OFDI in terms of the ratio of its OFDI to GDP over the same period [22].

Innovation Quality. Innovation quality is based on the concept of the total quality of products, services, processes, and operations. Liu (2019) uses the patent grant rate (the ratio of inventions to patent applications) to measure the quality of innovation [25]. The patent-granting rate reflects the enterprise's innovation ability, which indirectly reflects the operation and cooperation ability, management ability of various departments of the organization, and the ability to deal with changes in the host country's market, which is the embodiment of comprehensive ability. A higher patent grant rate indicates a higher 
quality of innovation; hence, we use the patent grant rate to measure the innovation quality of high-technology enterprises operating across borders.

Knowledge absorptive capacity. Smith (2005) showed that knowledge absorptive capacity reflects firms' innovative attitudes and behaviors towards knowledge sources [46]. Cohen and Levinthal (1990) have argued that knowledge absorptive capacity is the ability of a firm to learn and imitate new knowledge technologies, and it can also be expressed in terms of the R\&D expenditures used to treat knowledge absorptive behavior [47]. Therefore, we use $R \& D$ intensity to express absorptive capacity, specifically taking the ratio of $R \& D$ expenditure to net assets.

Control variables. Based on the host government's potential challenge and rejection of multinational enterprise development, we select firm size, firm age, firm performance, operational efficiency, and industry growth rate to monitor the development strength of multinational enterprises. Environmental instability, overseas R\&D breadth, and overseas $R \& D$ depth are also used as influencing factors to indicate the innovation diffusion behavior of the parent company's innovation R\&D investment in its subsidiaries.

Firm size. Organizational theory emphasizes that the size of the firm affects the organization's ability to withstand the external environment and its strategic attitude towards innovation with redundant resources, which indirectly reflects the comprehensive ability of the enterprise. Numerous studies have confirmed the correlation between firm size and resource innovation; thus, we measure firm size using the natural logarithm of total assets at the end of each year.

Firm age. The age of the company reflects the viability of entering the industry, which will have a great impact on the accumulation of resources and the ability to absorb knowledge as well as the trust of the host country. The age of the enterprise also has an impact on resilience to external risks, which is usually measured by the number of days from the date of establishment to the end of each year (December 31); thus, we take the natural logarithm of the age of the enterprise on this basis.

Firm performance. Firms tend to accumulate capital when they are performing well and consume it when they experience troughs in performance. We consider that high and low performance affects capital accumulation, host country recognition, and acceptance, and that firms have different attitudes towards resource allocation, such as conservative and exploratory, depending on performance, which indirectly affects their development progress. Therefore, we use the net interest rate on total assets to measure firm performance.

Operational Efficiency. An enterprise's liquidity and operational performance will affect the accumulation of capital and its ability to defend itself against risks, and it will not be able to maintain basic operations in poor condition. Knowledge management theory suggests that the efficiency of knowledge uptake is related to the operational status of the firm; therefore, we use the annual total asset turnover rate to measure operational efficiency.

Industry growth rate. The market structure, demand, and development of the host country are different from that of the home country. Meanwhile, there are differences in the growth of the industries to which enterprises belong. Different growth rates will have an impact on overall enterprise development, strategic planning, innovation efficiency, and resource utilization. We measure the growth rate relative to the beginning of the year using the sum of the year-end assets of all listed companies in our industry.

Environmental instability. The speed and differentiation of the environment can cause changes within the company. Host country culture, religion, policy, and other factors will have an impact on the development of multinational enterprises, the stability and maturity of the market determine the success of corporate strategy and innovation. We use the variance measure of the firm's ROA (return on assets = net profit after tax/total assets) for the first three years based on existing research.

Overseas R\&D depth. Overseas R\&D depth is the proportion of R\&D investment carried out by multinational enterprises in neighboring countries to all multinational investment, and higher R\&D investment can enhance the recognition of host countries. Therefore, drawing on the research of Hsu (2015) [37], we measured the number of a 
firm's foreign R\&D subsidiaries by dividing the total number of foreign subsidiaries in a given year.

Overseas R\&D breadth. Firms invest in R\&D in different host countries to access different sources of knowledge, which manifests itself in geographic dispersion; the wider the coverage, the more diverse the knowledge that can be searched, identified, and absorbed. By adding new elements to a company's knowledge set, the company increases the likelihood that it will discover new value ideas. Therefore, we draw on Redding et al.'s research to measure overseas R\&D breadth using the number of countries or regions in which a firm invests in overseas R\&D subsidiaries [52].

In summary, the definitions of the variables as summarized in this paper, are shown in Table 1.

Table 1. Variables and definitions.

\begin{tabular}{|c|c|}
\hline Variable & Definition \\
\hline OFDI & The ratio of OFDI to GDP over the same period \\
\hline Innovative quality (IQ) & The ratio of patents invented to patents filed \\
\hline Knowledge absorptive capacity (KA) & The ratio of $R$ \& $D$ expenditure to net assets \\
\hline Firm size (Size) & Natural logarithm of total assets at the end of each year \\
\hline Firm age (Age) & $\begin{array}{l}\text { Natural logarithm of the number of days from the date } \\
\text { of incorporation of the parent company to the end of } \\
\text { each year (December 31) }\end{array}$ \\
\hline Firm performance $(\mathrm{BP})$ & Total net assets margin \\
\hline Operational efficiency (Operation) & Annual total assets turnover rate \\
\hline Industry growth rate (Growth) & $\begin{array}{l}\text { The growth rate of total assets at the end of the year } \\
\text { relative to total assets at the beginning of the year }\end{array}$ \\
\hline Environmental instability (EI) & $\begin{array}{c}\text { The variance of ROA (return on assets = net profit after } \\
\text { tax/total assets) over the previous three years }\end{array}$ \\
\hline Overseas R\&D depth (ORDD) & $\begin{array}{l}\text { Number of a firm's foreign R\&D subsidiaries divided by } \\
\text { the total number of foreign subsidiaries in a given year }\end{array}$ \\
\hline Overseas R\&D breadth (ORDB) & $\begin{array}{c}\text { Number of countries or regions in which the company } \\
\text { has invested in overseas R\&D subsidiaries }\end{array}$ \\
\hline
\end{tabular}

\subsection{Methods}

To test the relationship between OFDI, knowledge absorptive capacity, and innovation quality of high-technology multinational enterprises, we used Edward and Lambert's (2007) moderated path analysis to test the hypothesis [64]. Edward and Lambert's (2007) moderated path analysis is a full-effects regulatory model that provides a complete analysis of the regulatory effects on all possible paths in an intermediary model. The model allows a clear analysis of the moderating effects between the independent variable $X$ and the mediating variable $M$, the regulating effect between the mediating variable $M$ and the dependent variable $Y$, and the regulating effect between the direct effects $X$ and $Y$. Ultimately, it can reveal the specific path of the moderating effect occurring on the mediation effect model path between the independent variable $X$ and the dependent variable $Y$. Specifically, the moderated path analysis consists of two major equations.

$$
\begin{gathered}
Y=\alpha_{1}+\alpha_{2} X+\alpha_{3} M+\alpha_{4} Z+\alpha_{5} X Z+\alpha_{6} M Z+e_{Y}+\varepsilon_{Y} \\
M=\beta_{1}+\beta_{2} X+\beta_{3} Z+\beta_{4} X Z+e_{M}+\varepsilon_{M}
\end{gathered}
$$

where $X$ is the independent variable OFDI, $Y$ is the dependent variable innovation quality, $M$ is the mediating variable knowledge absorptive capacity, $Z$ is the moderating variable, $e$ denotes the random error term, and $\varepsilon$ denotes the random perturbation term. Edward and Lambert (2007) proposed that nonlinear relationships can be regarded as a special case of regulation to solve the verification of nonlinear relations. The role of the independent variable depends on the level of the independent variable itself, which can be verified by replacing $Z$ with $X$ in the equation, where $X$ and $Z$ are the same variables, 
implying that $X Z$ is the quadratic term of OFDI. $M Z$ is the interaction term between knowledge absorptive capacity and OFDI. In combination with the characteristics of panel data, Equations (1) and (2) are set as follows.

$$
\begin{gathered}
Y_{i, t}=\eta_{1}+\eta_{2} X_{i, t}+\eta_{3} X_{i, t}{ }^{2}+\eta_{4} M_{i, t}+\eta_{5} M_{i, t} X_{i, t}+\eta_{6} \text { control }_{i, t}+e_{Y i, t}+\varepsilon Y_{i, t} \\
M_{i, t}=\lambda_{1}+\lambda_{2} X_{i, t}+\lambda_{3} X_{i, t}{ }^{2}+\lambda_{4} \text { control }_{i, t}+e_{M i, t}+\varepsilon_{M_{i, t}}
\end{gathered}
$$

where $i$ represented the enterprise and $t$ represents the year. $X$ is the independent variable OFDI, $Y$ is the dependent variable innovation quality (IQ), $M$ is the mediating variable knowledge absorptive capacity (KA). The control variables include firm size (Size), firm age (Age), firm performance (FP), operational efficiency (OE), industry growth rate (Growth), environmental instability (EI), overseas R\&D depth (ORDD), overseas R\&D breadth (ORDB). Equation (3) allows the total effect between the dependent and independent variables, the independent variable squared, the mediating variable, and the interaction term between the independent and mediating variable to be tested separately. We tested the non-linear relationship between OFDI and innovation quality and the mediating transmission of knowledge absorptive capacity between them through Equation (3). Equation (4) tests the non-linear relationship between OFDI and knowledge absorption capacity.

\section{Results}

\subsection{Measure Validation and Descriptive Statistics}

We conducted the empirical analysis using the software Stata 14.0, and Table 2 presents the descriptive statistics of the regression variables, with outliers removed from the sample.

Table 2. Descriptive statistics (eliminating outliers).

\begin{tabular}{cccccc}
\hline Variable & Obs & Std. Dev. & Mean & Minimum & Maximum \\
\hline OFDI & 2868 & 1.206 & 2.388 & 0.002 & 6.987 \\
IQ & 2868 & 0.245 & 0.160 & 0.005 & 1.000 \\
KA & 2868 & 1.345 & 3.974 & 0.268 & 7.126 \\
Size & 2868 & 1.247 & 12.092 & 6.144 & 17.059 \\
Age & 2868 & 1.526 & 12.956 & 8.004 & 18.335 \\
FP & 2868 & 1.526 & 6.048 & 1.097 & 11.427 \\
Operation & 2868 & 0.406 & 0.679 & 0.006 & 3.835 \\
Growth & 2868 & 1.863 & 2.994 & 1.001 & 7.999 \\
EI & 2868 & 0.112 & 0.101 & 0.001 & 0.730 \\
ORDD & 2868 & 0.400 & 0.145 & 0.000 & 5.690 \\
ORDB & 2868 & 0.767 & 2.363 & 0.142 & 6.541 \\
\hline
\end{tabular}

Before analyzing the relationships between the variables, we tested the correlations between the variables. The results are shown in Table 3. From the correlation coefficient matrix in Table 3, the results of correlation of variables, the correlations between OFDI, knowledge absorptive capacity, and innovation quality were significant while there was a difference in the significant correlations between the control variables and the explained variables. The correlation coefficients were all less than the threshold of 0.7 . We performed a multicollinearity test on the variables using the variance inflation factor (VIF); the results are shown in Table 3. Max $\{\mathrm{VIF} 1, \mathrm{VIF} 2 \ldots\}=5.76<10$, indicating that there is no multicollinearity in the variables and the baseline regression can be carried out. To ensure the accuracy of the analysis, we centered the data of each variable to avoid multicollinearity. The results of the Hausman test enabled rejection of the original hypothesis of a random effects model; thus, we used a fixed effects model for the measurement analysis. 
Table 3. Correlation matrix (eliminating outliers).

\begin{tabular}{|c|c|c|c|c|c|c|c|c|c|c|c|}
\hline Variables & (1) & (2) & (3) & (4) & (5) & (6) & (7) & (8) & (9) & (10) & (11) \\
\hline Size & - & & & & & & & & & & \\
\hline Age & $0.370 * * *$ & - & & & & & & & & & \\
\hline $\mathrm{FP}$ & $0.576^{* * *}$ & $0.631^{* * *}$ & - & & & & & & & & \\
\hline Operation & $-0.199 * * *$ & $0.062^{* * *}$ & $0.059 * * *$ & - & & & & & & & \\
\hline growth & $-0.265^{* * *}$ & $-0.394^{* * *}$ & $-0.327^{* * *}$ & 0.009 & - & & & & & & \\
\hline EI & -0.029 & $-0.126^{* * *}$ & $-0.118^{* * *}$ & $-0.136^{* * *}$ & $0.105^{* * *}$ & - & & & & & \\
\hline ORDD & $0.139 * * *$ & $0.236^{* * *}$ & $0.477^{* * *}$ & $0.216^{* * *}$ & $-0.153^{* * *}$ & $-0.452 * * *$ & - & & & & \\
\hline ORDB & $0.381 * * *$ & $0.359 * * *$ & $0.360 * * *$ & $0.225^{* * *}$ & $0.117^{* * *}$ & $0.461^{* *}$ & $0.307^{* * *}$ & - & & & \\
\hline IQ & -0.011 & $0.054^{* * *}$ & $0.063^{* * *}$ & $0.077^{* * *}$ & $-0.221^{* * *}$ & $-0.216^{* * *}$ & $-0.248^{* * *}$ & 0.009 & 3.810 & & \\
\hline KA & $0.405^{* * *}$ & $0.328^{* * *}$ & $0.323^{* * *}$ & -0.095 & $-0.124^{* * *}$ & $0.535^{* * *}$ & $0.273^{* * *}$ & $0.718^{* * *}$ & $0.346^{* * *}$ & 4.590 & \\
\hline OFDI & $0.504^{* * *}$ & $0.468^{* * *}$ & $0.469^{* * *}$ & $-0.138^{* * *}$ & $0.273 * * *$ & $-0.046^{* * *}$ & $-0.180 * * *$ & $0.539 * * *$ & $0.183^{* * *}$ & $0.413^{* * *}$ & 5.760 \\
\hline
\end{tabular}

\subsection{Inter-Group Heteroscedasticity, Autocorrelation, and Simultaneous Correlation Tests}

Since the data of 478 multinational enterprises used in the construction of the model comprise panel data, which are different from cross-sectional data and time-series data, a panel estimation strategy was needed. Therefore, this study focused on fixed effects, random effects, inter-group heteroscedasticity, autocorrelation, or inter-group simultaneous correlation, which may affect the accuracy of parameter estimation. First, we used the Hausman test method to test whether a random or fixed effect model applied; the results enabled the original hypothesis to be rejected, so the fixed effect model was adopted. Then, we used the White test to examine the heteroscedasticity issue. Table 4 shows that the chi-square test statistic was 790.75, and the $p$-value was 0 , strongly rejecting the original assumption of the same variance, thus, the measurement model of this study has heteroscedasticity.

Table 4. Heteroscedasticity test (White).

\begin{tabular}{cc}
\hline \multicolumn{3}{c}{ H0: Sigma(i)^2 $=$ Sigma^2 for All i } \\
\hline chi2 (27) & 790.75 \\
Prob > chi2 & 0.000 \\
Fixed effects & YES \\
\hline
\end{tabular}

In addition, we used the Wald test in the comprehensive GLS model to test autocorrelation. The results in Table 5 show that, regardless of whether the control time and individual effect were controlled, the intra-group autocorrelation test results enabled rejection of the null hypothesis that there was no first-order intra-group autocorrelation, and that there was intra-group autocorrelation.

Table 5. Autocorrelation test.

\begin{tabular}{cc}
\hline \multicolumn{2}{c}{ H0: No First-Order Autocorrelation } \\
\hline F & 4.920 \\
Prob $>$ F & 0.0623 \\
Fixed Effects & YES \\
\hline
\end{tabular}

Furthermore, we used the Breusch-Pagan LM method to test the correlation. The results are shown in Table 6. The $p$-value of the Breusch-Pagan LM test was 0.0189, indicating that the original hypothesis could be rejected and that there was a simultaneous correlation. 
Table 6. Simultaneous correlation tests.

\begin{tabular}{cc}
\hline \multicolumn{2}{c}{ Ho: $\operatorname{COV}\left(-{ }_{i_{1}} t-i_{2} t\right)=0$} \\
\hline Breusch-Pagan LM test of \\
independence \\
$\begin{array}{cc}\text { Pr } \\
\text { Fixed effects }\end{array}$ & 93.107 \\
YES \\
\hline
\end{tabular}

The heteroscedasticity and autocorrelation test results of the above panel data showed that heteroscedasticity, simultaneous correlation, and intra-group autocorrelation existed simultaneously. When there are heteroscedasticity and simultaneous correlation in the model and the OLS results are still consistent, the panel correction standard error model analysis (PCSE) can be used. The autocorrelation problem will have a greater impact on the results of the estimated parameters. Based on existing research, we used the AR model and PAAR model in generalized least squares (FGLS) to solve the autocorrelation problem of panel data. Finally, whether an AR or PAAR model is selected depends on the results of comprehensive FGLS. The comprehensive generalized least squares (FGLS) method can comprehensively address the three factors of heteroscedasticity, autocorrelation, and simultaneous correlation. The principle of FGLS estimation is to conduct OLS estimation first, and then use residuals to estimate the covariance matrix, to conduct iterative FGLS estimation until convergence. Therefore, based on the OLS model, we selected the FGLS model (AR and PSA) with the same autoregressive coefficient and different autoregressive coefficients, the PCSE model with panel correction standard error estimation, and the comprehensive FGLS model for regression estimation.

\subsection{Hypotheses Tests}

To solve the problems of heteroscedasticity, autocorrelation, and synchronization, the benchmark regression was tested by OLS, AR, PSAR, PCSE, and FGLS models, respectively, as shown in Tables 7 and 8.

Table 7. OFDI, knowledge absorptive capacity, and innovation quality ( $\mathrm{N}=478)$ (eliminating outliers).

\begin{tabular}{cccccc}
\hline \multirow{2}{*}{ Variable } & \multicolumn{5}{c}{ Innovation Quality (IQ) } \\
\cline { 2 - 6 } & $\mathbf{( O L S )}$ & $\mathbf{( A R )}$ & $\mathbf{( P S A R )}$ & $\mathbf{( P C S E )}$ & $\mathbf{( F G L S )}$ \\
\hline \multirow{2}{*}{ Size } & $-0.046^{* * *}$ & $-0.051^{* * * *}$ & $-0.049^{* * *}$ & $-0.062^{* * *}$ & $-0.044^{* * *}$ \\
& $(0.011)$ & $(0.019)$ & $(0.023)$ & $(0.021)$ & $(0.009)$ \\
Age & -0.227 & -0.209 & -0.352 & -0.209 & $-0.371^{*}$ \\
& $(0.672)$ & $(0.613)$ & $(0.592)$ & $(0.672)$ & $(0.501)$ \\
FP & 0.038 & 0.032 & 0.029 & 0.002 & 0.073 \\
& $(0.054)$ & $(0.063)$ & $(0.092)$ & $(0.101)$ & $(0.048)$ \\
Operation & $-0.126^{* * *}$ & $-0.178^{* * *}$ & $-0.203^{* * *}$ & $-0.217^{* * *}$ & $-0.302^{* * *}$ \\
& $(0.017)$ & $(0.019)$ & $(0.020)$ & $(0.011)$ & $(0.008)$ \\
Growth & $-0.165^{* * *}$ & $-0.153^{* * *}$ & $-0.187^{* * *}$ & $-0.111^{* * *}$ & $-0.159^{* * *}$ \\
& $(0.022)$ & $(0.019)$ & $(0.015)$ & $(0.013)$ & $(0.021)$ \\
EI & $-0.758^{* * *}$ & $-0.663^{* * * *}$ & $-0.715^{* * *}$ & $-0.698^{* * *}$ & $-0.652^{* * *}$ \\
& $(0.089)$ & $(0.084)$ & $(0.076)$ & $(0.099)$ & $(0.071)$ \\
ORDD & $-0.099^{* * *}$ & $-0.115^{* * *}$ & $-0.146^{* * *}$ & $-0.194^{* * *}$ & $-0.159^{* * *}$ \\
& $(0.011)$ & $(0.016)$ & $(0.019)$ & $(0.009)$ & $(0.012)$ \\
ORDB & 0.238 & $0.241^{* *}$ & $0.257^{* *}$ & $0.236^{* *}$ & $0.279^{* * *}$ \\
& $(0.017)$ & $(0.020)$ & $(0.016)$ & $(0.025)$ & $(0.019)$ \\
OFDI & -0.031 & -0.056 & -0.062 & -0.071 & $-0.126^{* *}$ \\
& $(0.014)$ & $(0.016)$ & $(0.013)$ & $(0.020)$ & $(0.018)$ \\
OFDI ${ }^{*}$ & $-0.025^{*}$ & $-0.086^{* *}$ & $-0.071^{* *}$ & $-0.112^{* * *}$ & $-0.096^{* * *}$ \\
& $(0.001)$ & $(0.002)$ & $(0.001)$ & $(0.001)$ & $(0.002)$ \\
\hline
\end{tabular}


Table 7. Cont.

\begin{tabular}{cccccc}
\hline \multirow{2}{*}{ Variable } & \multicolumn{5}{c}{ Innovation Quality (IQ) } \\
\cline { 2 - 6 } & (OLS) & (AR) & (PSAR) & (PCSE) & (FGLS) \\
\hline \multirow{2}{*}{ KA } & $-0.023^{*}$ & $-0.029^{* *}$ & $-0.026^{* *}$ & $-0.031^{* *}$ & $-0.037^{* * *}$ \\
& $(0.006)$ & $(0.004)$ & $(0.002)$ & $(0.003)$ & $(0.001)$ \\
KA*OFDI & $0.013^{*}$ & $0.024^{* * *}$ & $0.033^{* * *}$ & $0.021^{* * *}$ & $0.034^{* * *}$ \\
Adjusted-R & $(0.005)$ & $(0.001)$ & $(0.003)$ & $(0.002)$ & $(0.001)$ \\
Fixed effects & $0.217^{*}$ & 0.358 & $0.416^{*}$ & 0.559 & 0.623 \\
\hline YES & YES & YES & YES & YES \\
\hline
\end{tabular}

Note: The model omits the constant term; ${ }^{*} p<0.1,{ }^{* *} p<0.05,{ }^{* * *} p<0.01$.

Table 8. OFDI and knowledge absorptive capacity $(\mathrm{N}=478)$ (eliminating outliers).

\begin{tabular}{|c|c|c|c|c|c|}
\hline \multirow{2}{*}{ Variable } & \multicolumn{5}{|c|}{ Knowledge Absorptive Capacity (KA) } \\
\hline & (OLS) & (AR) & (PSAR) & (PCSE) & (FGLS) \\
\hline \multirow{2}{*}{ Size } & -0.091 & -0.102 & -0.093 & -0.112 & $-0.136 *$ \\
\hline & $(0.131)$ & $(0.090)$ & $(0.251)$ & $(0.096)$ & $(0.087)$ \\
\hline \multirow{2}{*}{ Age } & 14.249 & 13.176 & $12.091 *$ & $14.794^{* *}$ & $12.315^{* *}$ \\
\hline & $(4.163)$ & $(4.098)$ & $(2.997)$ & $(2.655)$ & $(1.963)$ \\
\hline \multirow{2}{*}{$\mathrm{FP}$} & $-1.327^{* * *}$ & $-1.019^{* * *}$ & $-1.465^{* *}$ & $-2.072 * * *$ & $-1.618^{* * *}$ \\
\hline & $(0.418)$ & $(0.551)$ & $(1.451)$ & $(1.643)$ & $(0.832)$ \\
\hline \multirow{2}{*}{ Operation } & $-0.468 * * *$ & $-0.453^{* * *}$ & $-0.427^{* * *}$ & $-0.596^{* * *}$ & $-0.537^{* * *}$ \\
\hline & $(0.126)$ & $(0.130)$ & $(0.247)$ & $(0.265)$ & (0.118) \\
\hline \multirow{2}{*}{ Growth } & -0.095 & -0.087 & $-0.108^{*}$ & $-0.115^{* *}$ & $-0.109^{* *}$ \\
\hline & $(0.246)$ & $(0.201)$ & $(0.176)$ & $(0.143)$ & $(0.152)$ \\
\hline \multirow{2}{*}{ EI } & $-2.334^{* * *}$ & $-2.118^{* * *}$ & $-1.942^{* * *}$ & $-2.681^{* * *}$ & $-1.993^{* * *}$ \\
\hline & $(0.617)$ & (0.599) & $(0.608)$ & $(0.507)$ & $(0.492)$ \\
\hline \multirow{2}{*}{ ORDD } & 0.252 * & $0.241^{* * *}$ & $0.317^{* * *}$ & $0.208^{* * *}$ & $0.291^{* * *}$ \\
\hline & $(0.138)$ & $(0.133)$ & $(0.152)$ & $(0.179)$ & $(0.107)$ \\
\hline \multirow{2}{*}{ ORDB } & 1.095 * & $1.378^{* * *}$ & $1.491^{* * *}$ & $2.015^{* * *}$ & $1.534^{* * *}$ \\
\hline & $(0.102)$ & $(0.091)$ & $(0.096)$ & $(0.132)$ & $(0.083)$ \\
\hline \multirow{2}{*}{ OFDI } & 0.332 * & $0.318 * *$ & $0.297^{* *}$ & $0.372 * *$ & $0.405^{* * *}$ \\
\hline & $(0.088)$ & $(0.076)$ & $(0.092)$ & $(0.128)$ & $(0.079)$ \\
\hline \multirow{2}{*}{$\mathrm{OFDI}^{2}$} & $-0.128 * *$ & $-0.107^{* *}$ & $-0.086^{* *}$ & $-0.119 * * *$ & $-0.219^{* * *}$ \\
\hline & $(0.014)$ & $(0.033)$ & $(0.102)$ & $(0.084)$ & (0.009) \\
\hline Adjusted-R ${ }^{2}$ & 0.322 & 0.393 & 0.573 & 0.541 & 0.619 \\
\hline Fixed effects & YES & YES & YES & YES & YES \\
\hline
\end{tabular}

Table 7 shows the regression results for OFDI, knowledge absorptive capacity, and innovation quality. In these five models, control variables, foreign direct investment, foreign direct investment square, and their interaction were included. The results of OLS, AR, PSAR, PCSE, and FGLS models show that OFDI was significantly negatively related to innovation quality; and the squared term of OFDI was significantly negatively related to innovation quality, and Hypothesis $\mathrm{H} 1$ is valid. The results showed an inverted Ushaped curvilinear relationship between OFDI and innovation quality in high technology enterprises. The results also imply that lower levels of OFDI promote innovation quality improvement, and when the level of investment is higher, greater OFDI inhibits innovation quality improvement, as shown in Figure 2. However, in these five models, only the adjusted R-square in the comprehensive FGLS model was better, and the coefficients were more pronounced than other models. Therefore, we chose the FGLS model to solve the heteroscedasticity, autocorrelation, and simultaneous correlation problems. 


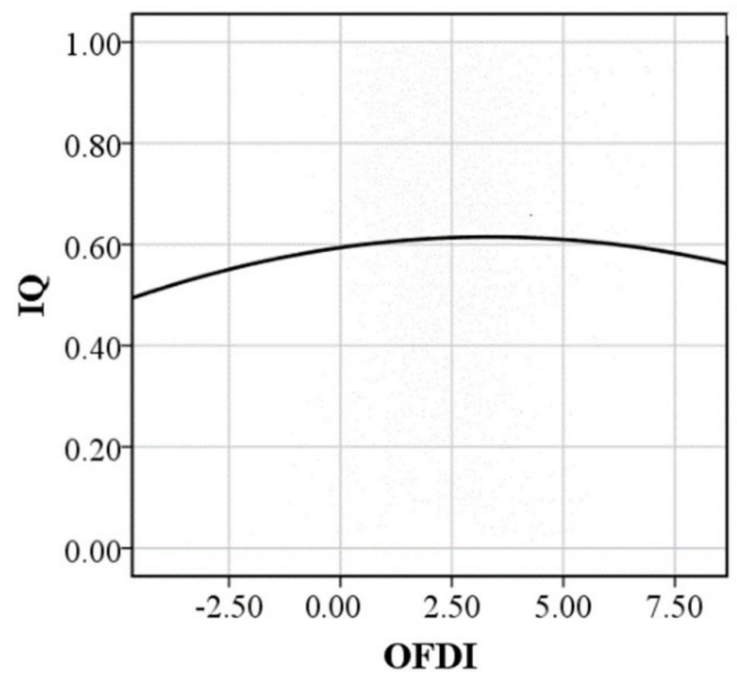

Figure 2. OFDI and Innovation quality.

Table 8 is mainly used to test the mediating effect of knowledge absorptive capacity. The squared terms of OFDI and OFDI were added to OLS, AR, PSAR, PCSE, and FGLS models, respectively. The results showed that OFDI was significantly negatively related to knowledge absorptive capacity, and the squared term of OFDI was significantly negatively related to knowledge absorptive capacity. The results indicate an inverted U-shaped relationship between OFDI and the absorptive capacity of high-tech enterprises, and Hypothesis $\mathrm{H} 2$ is verified. The results also imply that a lower OFDI promotes knowledge absorptive capacity, and when the level of investment reaches a certain level, a greater degree of OFDI inhibits knowledge absorptive capacity, as shown in Figure 3. Meanwhile, in these five models, only the adjusted R-square in the comprehensive FGLS model was better, and the coefficients were more pronounced than other models. Therefore, we chose the FGLS model to solve the heteroscedasticity, autocorrelation, and simultaneous correlation problems.

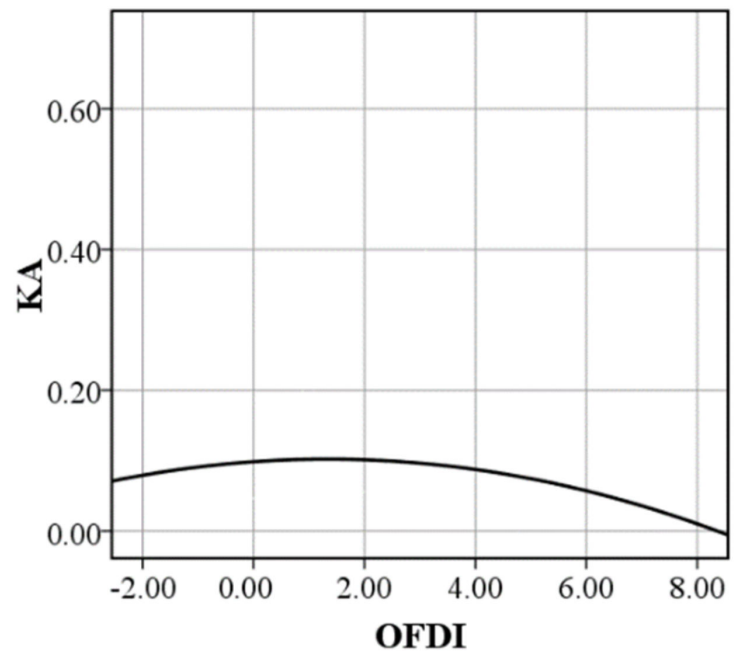

Figure 3. OFDI and knowledge absorptive capacity.

According to Edward and Lambert's (2007) moderated path analysis, a comparative analysis of the direct and indirect effect models of OFDI with knowledge absorptive capacity and innovation quality is needed. Table 7 adds knowledge absorptive capacity, knowledge absorptive capacity, and an OFDI interaction term, and the results show that the interaction term results were significant. This means that knowledge absorptive capacity and innovation quality were affected by OFDI. The squared term of OFDI and innovation 
quality was significantly negative, indicating that the relationship between OFDI and innovation quality was not changed by the addition of the interaction term of knowledge absorptive capacity and OFDI, knowledge absorptive capacity. In summary, OFDI by high-tech enterprises affected knowledge absorptive capacity through the inverted Ushaped curve effect, which further affected innovation quality, promoting an inverted Ushaped relationship between OFDI and innovation quality in Chinese high-tech enterprises; therefore, hypothesis $\mathrm{H} 3$ is verified.

\subsection{Post Hoc Analysis}

Considering that different levels of investment will have different impacts on the ability of multinational enterprises to adapt to the host country, to further analyze the level of capital accumulation of Chinese high-tech multinational enterprises at the present stage, it was necessary to clarify whether more or less OFDI will have a positive impact on the quality of innovation of high-tech multinational enterprises. We used the model to divide the sample of enterprises into a low-degree OFDI group and a high-degree OFDI group, using the median OFDI to help enterprises determine which investment strategy is conducive to innovation quality improvement [6]. We tested for outward foreign direct investment (OFDI) in high technology enterprises with a median OFDI value of 2.388 and, based on this median value, the sample was divided into a low OFDI group of 240 and a high OFDI group of 238, as shown in Table 9.

Table 9. The results of the post hoc analysis on OFDI (eliminating outliers).

\begin{tabular}{|c|c|c|c|c|c|c|c|c|c|c|}
\hline \multirow{3}{*}{ Variable } & \multicolumn{10}{|c|}{ Comprehensive FGIS Test } \\
\hline & \multicolumn{5}{|c|}{ Low-Degree OFDI Group(N = 240) } & \multicolumn{5}{|c|}{ High-Degree OFDI Group(N = 238) } \\
\hline & KA & KA & IQ & IQ & IQ & KA & KA & IQ & IQ & IQ \\
\hline Size & $\begin{array}{c}0.056 \\
(0.080)\end{array}$ & $\begin{array}{c}0.061 \\
(0.082)\end{array}$ & $\begin{array}{c}-0.088^{* * *} \\
(0.019)\end{array}$ & $\begin{array}{c}-0.091^{* * *} \\
(0.020)\end{array}$ & $\begin{array}{c}-0.103^{* *} \\
(0.017)\end{array}$ & $\begin{array}{l}-0.109 \\
(0.142)\end{array}$ & $\begin{array}{l}-0.128 \\
(0.143)\end{array}$ & $\begin{array}{l}0.035 * * \\
(0.017)\end{array}$ & $\begin{array}{l}0.036^{* *} \\
(0.017)\end{array}$ & $\begin{array}{l}0.041^{* *} \\
(0.018)\end{array}$ \\
\hline Age & $\begin{array}{l}9.521 * \\
(5.076)\end{array}$ & $\begin{array}{l}9.677^{*} \\
(4.861)\end{array}$ & $\begin{array}{c}-2.120 * \\
(1.193)\end{array}$ & $\begin{array}{c}-2.239 * \\
(1.186)\end{array}$ & $\begin{array}{c}-2.568 * \\
(1.180)\end{array}$ & $\begin{array}{l}16.498 * \\
(2.142)\end{array}$ & $\begin{array}{l}12.993 \\
(2.502)\end{array}$ & $\begin{array}{l}2.635^{* *} \\
(0.980)\end{array}$ & $\begin{array}{c}2.712^{* * *} \\
(1.001)\end{array}$ & $\begin{array}{c}2.840^{* * *} \\
(1.002)\end{array}$ \\
\hline $\mathrm{FP}$ & $\begin{array}{c}-0.938^{* *} \\
(0.405)\end{array}$ & $\begin{array}{c}-0.887^{* *} \\
(0.407)\end{array}$ & $\begin{array}{l}0.176 * \\
(0.096)\end{array}$ & $\begin{array}{l}0.183 * * \\
(0.095)\end{array}$ & $\begin{array}{c}0.177 \\
(0.090)\end{array}$ & $\begin{array}{c}-1.533^{* *} \\
(0.791)\end{array}$ & $\begin{array}{c}-1.670 * \\
(0.730)\end{array}$ & $\begin{array}{c}-0.195^{* * *} \\
(0.075)\end{array}$ & $\begin{array}{c}-0.213^{* * *} \\
(0.077)\end{array}$ & $\begin{array}{c}-0.228^{* * *} \\
(0.080)\end{array}$ \\
\hline Operation & $\begin{array}{c}-0.754^{* * *} \\
(0.127)\end{array}$ & $\begin{array}{c}-0.801 * * * \\
(0.131)\end{array}$ & $\begin{array}{c}-0.093^{* * *} \\
(0.030)\end{array}$ & $\begin{array}{c}-0.101^{* * *} \\
(0.029)\end{array}$ & $\begin{array}{c}-0.104^{* * *} \\
(0.031)\end{array}$ & $\begin{array}{c}-0.482 * * \\
(0.173)\end{array}$ & $\begin{array}{c}-0.524^{* *} \\
(0.182)\end{array}$ & $\begin{array}{c}-0.181^{* * *} \\
(0.022)\end{array}$ & $\begin{array}{c}-0.183^{* * *} \\
(0.024)\end{array}$ & $\begin{array}{c}-0.188^{* * *} \\
(0.024)\end{array}$ \\
\hline Growth & $\begin{array}{c}-0.134^{* *} \\
(0.006)\end{array}$ & $\begin{array}{c}-0.206^{* *} \\
(0.008)\end{array}$ & $\begin{array}{c}-0.182 * * * \\
(0.013)\end{array}$ & $\begin{array}{c}-0.186^{* * *} \\
(0.012)\end{array}$ & $\begin{array}{c}-0.191^{* * *} \\
(0.012)\end{array}$ & $\begin{array}{c}-0.177^{* *} \\
(0.003)\end{array}$ & $\begin{array}{c}-0.180^{* *} \\
(0.003)\end{array}$ & $\begin{array}{c}0.096 \text { *** } \\
(0.088)\end{array}$ & $\begin{array}{c}0.121 * * * \\
(0.089)\end{array}$ & $\begin{array}{c}0.128^{* * *} \\
(0.095)\end{array}$ \\
\hline EI & $\begin{array}{c}-2.618^{* * *} \\
(0.600)\end{array}$ & $\begin{array}{c}-2.792 * * * \\
(0.581)\end{array}$ & $\begin{array}{c}-0.349 * * \\
(0.140)\end{array}$ & $\begin{array}{c}-0.355^{* * *} \\
(0.141)\end{array}$ & $\begin{array}{c}-0.438 * * * \\
(0.143)\end{array}$ & $\begin{array}{c}-2.233 * * \\
(1.056)\end{array}$ & $\begin{array}{c}-2.327^{* *} \\
(1.073)\end{array}$ & $\begin{array}{c}-0.865^{* * *} \\
(0.107)\end{array}$ & $\begin{array}{c}-0.887 * * * \\
(0.109)\end{array}$ & $\begin{array}{c}-0.901^{* * *} \\
(0.110)\end{array}$ \\
\hline ORDD & $\begin{array}{l}0.084 * \\
(0.046)\end{array}$ & $\begin{array}{c}0.138 \text { *** } \\
(0.050)\end{array}$ & $\begin{array}{c}-0.041 * * * \\
(0.010)\end{array}$ & $\begin{array}{c}-0.038 * \\
(0.011)\end{array}$ & $\begin{array}{l}-0.022 \\
(0.011)\end{array}$ & $\begin{array}{c}-1.217^{* * *} \\
(0.606)\end{array}$ & $\begin{array}{c}-1.358^{* * *} \\
(0.608)\end{array}$ & $\begin{array}{c}-0.320 * * * \\
(0.066)\end{array}$ & $\begin{array}{c}-0.322^{* * *} \\
(0.067)\end{array}$ & $\begin{array}{c}-0.326^{* * *} \\
(0.067)\end{array}$ \\
\hline ORDB & $\begin{array}{c}1.553^{* * *} \\
(0.109)\end{array}$ & $\begin{array}{c}1.549 \text { *** } \\
(0.089)\end{array}$ & $\begin{array}{c}0.151 \text { *** } \\
(0.025)\end{array}$ & $\begin{array}{c}0.147^{* * *} \\
(0.025)\end{array}$ & $\begin{array}{c}0.159 * * * \\
(0.027)\end{array}$ & $\begin{array}{c}1.286^{* * *} \\
(0.230)\end{array}$ & $\begin{array}{c}1.351 * * * \\
(0.231)\end{array}$ & $\begin{array}{c}0.270 * * * \\
(0.026)\end{array}$ & $\begin{array}{c}0.278^{* * *} \\
(0.028)\end{array}$ & $\begin{array}{c}0.281 * * * \\
(0.029)\end{array}$ \\
\hline OFDI & $\begin{array}{c}-0.144^{* *} \\
(0.051)\end{array}$ & $\begin{array}{c}0.048 \\
(0.090)\end{array}$ & $\begin{array}{c}0.009 \\
(0.018)\end{array}$ & $\begin{array}{l}0.028^{* *} \\
(0.026)\end{array}$ & $\begin{array}{c}0.075^{* * *} \\
(0.023)\end{array}$ & $\begin{array}{c}-0.657^{* * *} \\
(0.130)\end{array}$ & $\begin{array}{l}-0.241 \\
(0.472)\end{array}$ & $\begin{array}{c}-0.140 * * * \\
(0.018)\end{array}$ & $\begin{array}{c}-0.148 \text { *** } \\
(0.042)\end{array}$ & $\begin{array}{c}-0.177^{* * *} \\
(0.044)\end{array}$ \\
\hline $\mathrm{OFDI}^{2}$ & & $\begin{array}{c}-0.090^{* * *} \\
(0.031)\end{array}$ & & $\begin{array}{c}-0.025^{* * *} \\
(0.009)\end{array}$ & $\begin{array}{c}-0.037 * * * \\
(0.010)\end{array}$ & & $\begin{array}{l}-0.099 \\
(0.064)\end{array}$ & & $\begin{array}{c}0.012 \\
(0.009)\end{array}$ & $\begin{array}{c}0.015 \\
(0.008)\end{array}$ \\
\hline KA & & & & & $\begin{array}{c}-0.042^{* * *} \\
(0.020)\end{array}$ & & & & & $\begin{array}{l}0.062 * \\
(0.017)\end{array}$ \\
\hline $\mathrm{OFDI}^{*} \mathrm{KA}$ & & & & & $\begin{array}{l}0.051^{* * *} \\
(0.008)\end{array}$ & & & & & $\begin{array}{l}0.083^{* *} \\
(0.005)\end{array}$ \\
\hline $\begin{array}{c}\text { Adjusted- } \\
\mathrm{R}^{2}\end{array}$ & 0.516 & 0.532 & 0.465 & 0.574 & 0.607 & 0.401 & 0.503 & 0.427 & 0.569 & 0.611 \\
\hline $\begin{array}{l}\text { Fixed } \\
\text { effects }\end{array}$ & YES & YES & YES & YES & YES & YES & YES & YES & YES & YES \\
\hline
\end{tabular}

Note: The model omits the constant term; ${ }^{*} p<0.1,^{* *} p<0.05,{ }^{* * *} p<0.01$.

The results for the low-degree OFDI group show that the relationships between the variables in the low-degree OFDI group were generally consistent with the relationships between the variables in the overall sample. The squared term of OFDI was significantly negatively correlated with both knowledge absorptive capacity and innovation quality. The results show that OFDI by high-tech enterprises has an inverted U-shaped relationship with 
knowledge absorptive capacity and innovation quality, respectively, and knowledge absorptive capacity plays a mediating role in the inverted U-shaped relationship between OFDI and innovation quality, as shown in Figures 4 and 5. While the results of the regressions on the control variables produce biases, the stability of the regression analyses on OFDI, knowledge absorptive capacity, and innovation quality in high-technology enterprises was acceptable.

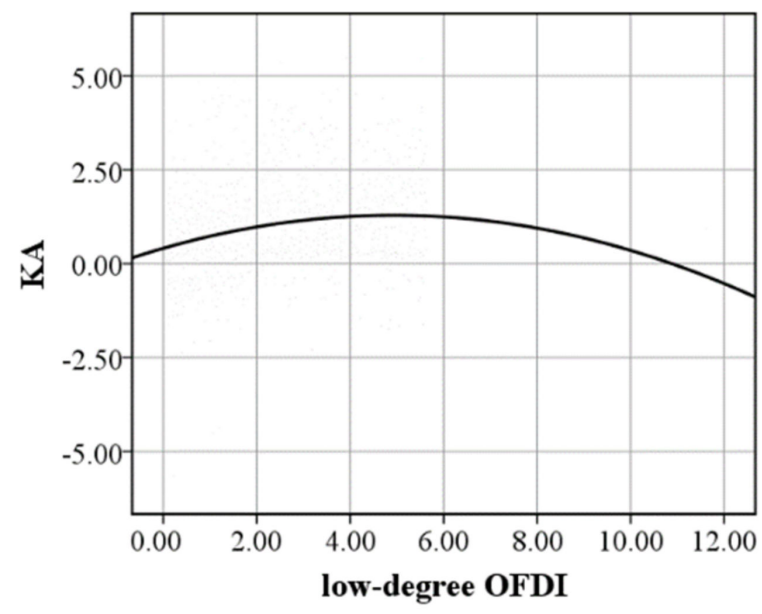

Figure 4. OFDI and KA (low-degree OFDI group).

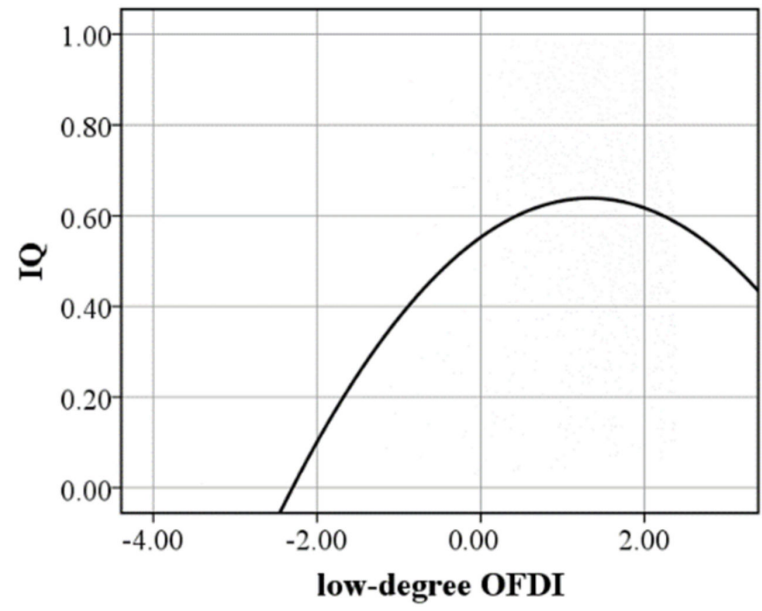

Figure 5. OFDI and IQ (low-degree OFDI group).

The results for the high-degree OFDI group showed that OFDI was negatively correlated with both pieces of knowledge absorptive capacity and innovation quality. The squared term of OFDI was not significantly associated with knowledge absorptive capacity and innovation quality while knowledge absorptive capacity positively affected innovation quality. The interaction term of OFDI and knowledge absorptive capacity(OFDI*KA) positively affected the quality of innovation. The results show that the higher the knowledge absorptive capacity, the better the relationship between OFDI and innovation quality; With increase in OFDI, the quality of innovation of high-technology enterprises decreases, and the knowledge absorption capacity can moderate the relationship between OFDI and the quality of innovation. However, since this sample is a high-degree OFDI group, the enterprises have a certain threshold for OFDI, as shown in Figure 6. Therefore, high-tech enterprises need to maintain a moderate degree of OFDI. 


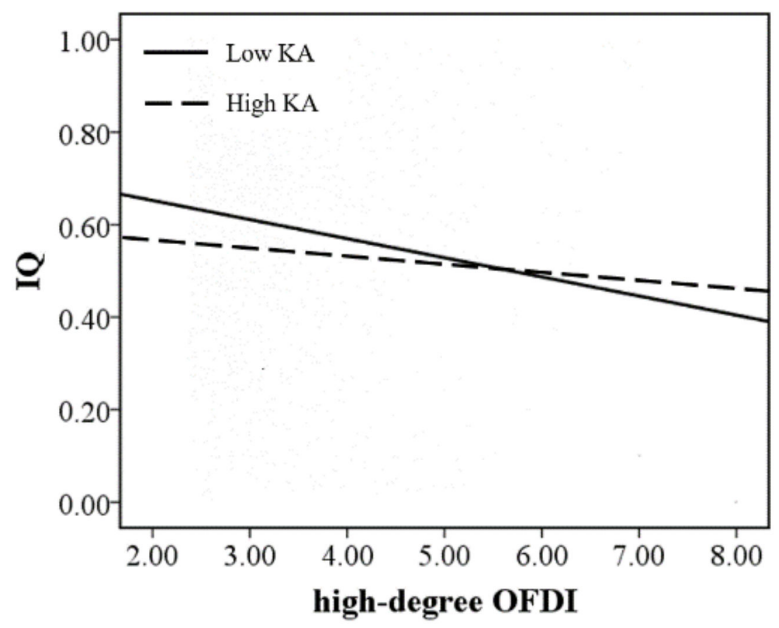

Figure 6. OFDI, KA and IQ (high-degree OFDI group).

\subsection{Endogeneity Test}

There are two main reasons that can lead to endogeneity problems. On the one hand, endogeneity problems occur when some of the explanatory variables are omitted. On the other hand, innovation quality may reverse outward foreign direct investment, resulting in endogenous problems. Thus, we used the instrumental variable method to solve the endogenous problem between outward foreign direct investment and innovation quality. Teece et al. (2018) used the OFDI probability of the enterprise as an instrumental variable for the OFDI of the enterprise. Therefore, we also used this method to test endogeneity, Equation (5) is set as follows:

$$
O F D I=b_{1}+b_{2} \text { market }+b_{3} T F P+b_{4} \text { finance }+e_{Y}+\varepsilon_{Y}
$$

where the explanatory variables are the factors affecting the development of OFDI, the market is representative of the degree of marketization, TFP represents the total factor productivity of the enterprise in a specific year, and finance is the ratio of total liabilities to total assets of the enterprise. For the Kleibergen-Paap Wald-RK-F-statistic, the value is much greater than the test critical value of 16.38 for the instrumental variables method, indicating that the instrumental variables method test in this paper is justified. The results are shown in Table 10.

Table 10. The results of the endogeneity test (eliminating outliers).

\begin{tabular}{ccc}
\hline & \multicolumn{2}{c}{ Instrumental Variable } \\
\cline { 2 - 3 } Variable & $\mathbf{( 1 )}$ & $\mathbf{( 2 )}$ \\
\cline { 2 - 3 } & Innovation Quality & Innovation Quality \\
\cline { 2 - 3 } OFDI & $-0.087^{* *}$ & $-0.046^{* *}$ \\
& $(0.021)$ & $(0.013)$ \\
OFDI $^{2}$ & $-0.025^{*}$ & $-0.017^{* *}$ \\
Kleibergen-Paap Rk Wald F & $(0.001)$ & $(0.003)$ \\
statistic & 111.34 & 71.39 \\
Time & 6 & 6 \\
Control & YES & YES \\
Year & Fixed & Fixed \\
$\mathrm{R}^{2}$ & 0.432 & 0.514 \\
$\mathrm{~N}$ & 478 & 478 \\
\hline
\end{tabular}

Note: The model omits the constant term; ${ }^{*} p<0.1$, $^{* *} p<0.05,{ }^{* * *} p<0.01$. 


\section{Discussion and Conclusions}

\subsection{Research Conclusions}

In general, with the promotion of a cross-border business model, the proportion of investment by Chinese high-tech enterprises in neighboring countries has been on the rise year after year. However, the multinational operation of the Chinese high-tech industry is still in the exploration stage, and Cheng (2010) points out that there is currently a serious imbalance between high quality and high-speed development in China's high-tech industry [26]. Currently, the diffusion effect of innovation from the parent company to its subsidiaries is not sufficiently significant, and the rational allocation of financial resources will be a breakthrough in improving the quality of innovation in Chinese enterprises [65-67]. Haner (2002) and Voss (2008) argue that there may be third-party variables, such as knowledge absorptive capacity, that influence the relationship between resources and high-quality development [1,2]. We reviewed the literature on the cross-border business model and argued that there may be some transmission mechanism among knowledge absorptive capacity, OFDI, and innovation quality. Based on data from a sample of 478 high-tech enterprises that made OFDI from China in 2013-2019, we validated the relationship using Edward and Lambert's (2007) moderated path analysis [64]. From the perspective of knowledge absorptive capacity, we investigated the relationship among the OFDI, absorptive capacity, and innovation quality of the cross-border business model, establishing the transmission mechanism among variables, and drawing the following main conclusions:

First, there is an inverted U-shaped relationship between OFDI and innovation quality in high-tech enterprises. More OFDI by enterprises is not always better. At the early stage of innovation development, a low degree of OFDI promotes innovation quality improvement; however, as it grows, a high degree of OFDI inhibits innovation quality improvement, and there is an optimal balance point between both.

Second, knowledge absorptive capacity plays an inverted U-shaped mediating role in the relationship between OFDI and innovation quality in high-tech enterprises. The existence of an inverted U-shaped relationship between OFDI and knowledge absorptive capacity means that OFDI affects knowledge absorptive capacity through the inverted U-shaped curve effect, which further affects innovation quality and contributes to the inverted U-shaped relationship between OFDI and innovation quality.

Third, the OFDI post hoc analysis further validates the relationship between the variables and explains the impact of different degrees of OFDI on the quality of innovation and knowledge absorptive capacity of high-tech multinational enterprises. There is a clear gap between the results of the OFDI post hoc analysis. OFDI and innovation quality were negatively correlated, and knowledge absorptive capacity positively moderated the relationship in the high-degree OFDI post hoc analysis. The empirical results in the lowdegree OFDI post hoc analysis were almost identical to those of the total sample. Although the results of the control variable regressions differ from the total sample results, which can produce a small degree of bias, it also indicates that the research hypothesis is largely free of logical problems and can be tested in practice.

\subsection{Theoretical Implications and Contributions}

With the further promotion of the Chinese cross-border business model, we analyze the high-quality development path from the perspective of OFDI of multinational enterprises in response to the continuous international investment disputes arising from the investment and operation of Chinese high-tech enterprises in neighboring countries, which aims to create an innovation diffusion effect on subsidiaries and reduce the incidence of investment disputes. Different from the previous understanding of the linear relationship between OFDI and innovation quality, we propose a non-linear model of the relationship between OFDI and innovation quality, taking into account the uncertainty of the host market and the development level of high-tech enterprises. The model illustrates whether more or less OFDI is better for the quality of innovation of multinational enterprises, and we verify the inverted U-shaped relationship between them. The research indicates that 
high-tech enterprises must maintain a balance of OFDI in the development process as the imbalance of investment may put them in a high-risk state, to the detriment of innovation exploration and high-quality development. Our research refines Voss's (2008) suggestion that enterprise resource allocation should further explore more complex non-linear relationships in different contexts [2]. Therefore, the inverted U-shaped relationship is not only a further development of the resource base theory but also deeply reflects the proposition of a mechanism to match the capabilities of OFDI, knowledge absorptive capacity, and innovation quality.

Our research breaks the traditional black box of mediating effects research and uses Edward and Lambert's (2007) moderated path analysis to test whether knowledge absorptive capacity has an inverted U-shaped mediating transmission between OFDI and innovation quality of the Chinese cross-border business model. As the policy, economic, cultural, and religious factors of the host country are quite different from those of Chinese society, which has a diversified impact on the development of multinational enterprises, the traditional three-step test of intermediary effects cannot reveal the path of influence of the intermediary variables. Therefore, we tested the hypothesis using the Edward and Lambert moderated path analysis method, which is a full-effects modulation model that provides a complete analysis of the modulation effects on all possible paths in the mediation model. OFDI has an inverted U-shaped relationship with knowledge absorptive capacity and innovation quality, respectively, indicating that knowledge absorptive capacity in high-tech multinationals is a reflection of the growth process and represents a mechanism of capability matching and adaptation. Meanwhile, it is also a sustainable development process of a two-way integration between multinational enterprises and host countries, which can achieve win-win cooperation between the two sides through local conditions and talent localization strategies. Therefore, matching OFDI by high-tech enterprises with the knowledge absorptive capacity of host countries, taking into account their development characteristics, is conducive to high-quality development in cross-border business.

We consider that the most important thing for Chinese high-tech enterprises in crossborder business to gain the acceptance and recognition of the host country is to balance the level of OFDI, which determines the rationalization of enterprise strategies and will reduce doubt and rejection. Multinational enterprises must establish a close link between OFDI and knowledge absorptive capacity by taking into account the host market, increasing the knowledge base, narrowing the cultural gap between enterprises and host countries. Chinese high-tech enterprises can change strategies through investment-level, and enhance knowledge spillovers, thereby improving absorptive capacity, which can increase integration and promote high-quality development. High-tech enterprises must maintain a moderate level of OFDI, which means the top of the inverted U-shaped curve. If OFDI is out of balance, when the level of investment is on the left-hand side of the inverted Ushaped curve, enterprises can adopt an incremental innovation model, focusing on product localization. The specific measure is to improve cultural integration, to ensure the quality of stakeholder services, to improve absorptive capacity and maintain basic operational infrastructure, and slowly improve the quality of innovation. When the level of OFDI is in an inverted U-shaped right-hand state, companies can adopt innovative breakthrough models that use large cash flows and financing networks to upgrade the skills of local employees and enhance the building of corporate and local cultures. While enhancing product uniqueness to gain a competitive advantage in the host market, the measure can boost local employment, increase knowledge absorption capacity, and further improve the Chinese cross-border business model.

\subsection{Limitations and Future Research}

First, although our research is supported by the data, the sample consists mainly of listed companies, and there is investigation of small and medium-sized multinational enterprises, which limits the generalizability of the research. Follow-up research should 
expand the sample source and industry category to increase the scope of application of the theory.

Second, based on the existing literature and the current development status of Chinese multinational enterprises, our research adopts OFDI as an overall variable to analyze its impact on innovation quality. However, OFDI is divided into M\&A and greenfield modes. Since the detailed data of M\&A and greenfield in high-tech enterprises in neighboring countries are missing, using M\&A and greenfield modes will affect the accuracy of highquality development of multinational enterprises. Therefore, we use the ratio of the amount of outward foreign direct investment (OFDI) by enterprises to GDP for the measurement of OFDI. At present, most academics study OFDI as a whole and studies that divide it into different dimensions are relatively lacking and underdeveloped. Thus, our research represents an extended and innovative approach in terms of OFDI. Therefore, as the main content of OFDI research, in the future, M\&A and greenfield modes of multinational enterprises should be studied in depth to expand their content and outreach.

Finally, our study does not consider the host country market environment and the internal and external institutional environment that may exist in the development of the cross-border business model, and we only analyze environmental turbulence as a control variable. Future research must further explore the impact of OFDI on quality development under the influence of the host country's political, cultural, and religious factors, such as cultural conflicts, bilateral policy coordination, and the formal or informal institutional environment. Moreover, we only study knowledge absorptive capacity as a mediating variable. In the future, we must consider the impact of the tacit explicit knowledge transfer effects of multinational enterprises on high-quality development. Therefore, researchers can further examine the extent of OFDI by multinational enterprises in the dynamic situation of host countries. Furthermore, we can research the relationship between knowledge transferability in investment patterns and innovation quality.

Author Contributions: Funding acquisition: D.X.; writing—review and editing: Q.C., writingoriginal draft: Q.C., M.Y., Y.S. and G.C.; visualization: Q.C., A.U. and X.W. All authors have read and agreed to the published version of the manuscript.

Funding: This work was supported by National Natural Science Foundation of China. The funding number is 71873118. And the funder is Professor Deping Xiong.

Institutional Review Board Statement: Not applicable.

Informed Consent Statement: Not applicable.

Data Availability Statement: Not applicable.

Acknowledgments: The authors thank the funders wholeheartedly for funding our research.

Conflicts of Interest: The authors declare no conflict of interest.

\section{References}

1. Haner, U.-E. Innovation quality-A conceptual framework. Int. J. Prod. Econ. 2002, 80, 31-37. [CrossRef]

2. Voss, G.B.; Sirdeshmukh, D.; Voss, Z.G. The effects of slack resources and environmental threat on product exploration and exploitation. Acad. Manag. J. 2008, 51, 147-164. [CrossRef]

3. Bernard, A.; Jensen, J.B.; Schott, P. Importers, Exporters, and Multinationals: A Portrait of Firms in the U.S. That Trade Goods. In Producer Dynamics: New Evidence from Micro Data; National Bureau of Economic Research: Cambridge, UK, 2005; pp. 513-552.

4. Wang, C.; Hong, J.; Kafouros, M.; Boateng, A. What drives outward FDI of Chinese firms? Testing the explanatory power of three theoretical frameworks. Int. Bus. Rev. 2012, 21, 425-438. [CrossRef]

5. Jordan, J.; Lowe, J.; Taylor, P. Strategy and Financial Policy in UK Small Firms. J. Bus. Financ. Account. 1998, 25, 1-27. [CrossRef]

6. Lichtenthaler, U. Open Innovation: Past Research, Current Debates and Future Directions. Acad. Manag. Perspect. 2011, 2, 75-93.

7. Nonaka, I.; von Krogh, G.; Voelpel, S. Organizational Knowledge Creation Theory: Evolutionary Paths and Future Advances. Organ. Stud. 2006, 27, 1179-1208. [CrossRef]

8. Bourgeois, L.J. On the Measurement of Organizational Slack. Acad. Manag. Rev. 1981, 6, 29-39. [CrossRef]

9. Hymer, S. The Efficiency (Contradictions) of Multinational Corporations. Am. Econ. Rev. 1970, 60, 441-448.

10. Fan, H.; Lin, F.; Tang, L. Minimum Wage and Outward FDI from China. J. Dev. Econ. 2018, 135, 1-19. [CrossRef] 
11. Caves, R.E. International Corporations: The Industrial Economics of Foreign Investment. Economica 1971, 38, 1-27. [CrossRef]

12. Bailey, M.A.; Strezhnev, A.; Voeten, E. Estimating Dynamic State Preferences from United Nations Voting Data. J. Confl. Resolut. 2016, 61, 430-456. [CrossRef]

13. Rugman, A.M.; Li, J. Will China's Multinationals Succeed Globally or Regionally? Eur. Manag. J. 2007, 25, 333-343. [CrossRef]

14. Sarkodie, S.A.; Adams, S.; Leirvik, T. Foreign direct investment and renewable energy in climate change mitigation: Does governance matter? J. Clean. Prod. 2020, 263, 121262. [CrossRef]

15. Desbordes, R.; Wei, S.-J. The effects of financial development on foreign direct investment. J. Dev. Econ. 2017, 127, 153-168. [CrossRef]

16. Isaksson, A.-S.; Kotsadam, A. Chinese aid and local corruption. J. Public Econ. 2018, 159, 146-159. [CrossRef]

17. Juran, J.M. On Quality by Design: The New Steps for Planning Quality into Goods and Services; Free Press: New York, NY, USA, 1992.

18. Dhahri, S.; Omri, A. Are international capital flows really matter for achieving SDGs 1 and 2: Ending poverty and hunger? Rev. World Econ. 2020, 156, 731-767. [CrossRef]

19. Wells, L.T. Third World Multinationals: The Rise of Foreign Investments from Developing Countries; The MIT Press: Cambridge, MA, USA, 1983.

20. Sarkodie, S.A.; Strezov, V. Effect of foreign direct investments, economic development and energy consumption on greenhouse gas emissions in developing countries. Sci. Total Environ. 2019, 646, 862-871. [CrossRef]

21. Wiklund, J.; Shepherd, D. Entrepreneurial orientation and small business performance: A configurational approach. J. Bus. Ventur. 2005, 20, 71-91. [CrossRef]

22. Deng, P. What determines performance of cross-border M\&As by Chinese companies? An absorptive capacity perspective Thunderbird Int. Bus. Rev. 2010, 52, 509-524. [CrossRef]

23. Wang, C.L. Entrepreneurial Orientation, Learning Orientation and Firm Performance. Entrep. Theory Pract. $2008,32,63-657$. [CrossRef]

24. Zhang, F.; Gallagher, K.S. Innovation and technology transfer through global value chains: Evidence from China's PV industry. Energy Policy 2016, 94, 191-203. [CrossRef]

25. Liu, T.; Wang, X.; Wing, T.W. The road to international currency: Global perspective and Chinese experience. Emerg. Mark. Rev. 2019, 38, 73-101. [CrossRef]

26. Cheng, L.K.; Ma, Z. China's Outward Foreign Direct Investment. In China's Growing Role in World Trade; Feenstra, R.C., Wei, S.J., Eds.; University of Chicago Press: Chicago, IL, USA, 2010; pp. 545-578. [CrossRef]

27. Thomas, L.S. Financing the Sustainable Development Goals. Sustainability 2020, 12, 2775.

28. Bezuidenhout, H.; Kleynhans, E.P.J. Modern Trends in Chinese Foreign Direct Investment in Africa: An OLI Approach. Manag. Glob. Transit. 2018, 16, 279-300. [CrossRef]

29. Bloom, N.; Reenen, J.V. Measuring and Explaining Management Practices Across Firms and Countries. Q. J. Econ. 2007, 122, 1351-1408. [CrossRef]

30. Manova, K. Credit constraints, equity market liberalizations and international trade. J. Int. Econ. 2008, 76, 33-47. [CrossRef]

31. Li, P.; Lu, Y.; Wang, J. Does flattening government improve economic performance? Evidence from China. J. Dev. Econ. 2016, 123, 18-37. [CrossRef]

32. Nocke, V.; Yeaple, S. Cross-border mergers and acquisitions vs. greenfield foreign direct investment: The role of firm heterogeneity. J. Int. Econ. 2007, 72, 336-365. [CrossRef]

33. Chesbrough, H.; Crowther, A.K. Beyond high tech: Early adopters of open innovation in other industries. RED Manag. 2006, 36, 229-236. [CrossRef]

34. Conconi, P.; Sapir, A.; Zanardi, M. The internationalization process of firms: From exports to FDI. J. Int. Econ. 2016, 99, 16-30. [CrossRef]

35. Daniel, F.; Lohrke, F.T.; Fornaciari, C.J.; Turner, R. Slack resources and firm performance: A meta-analysis. J. Bus. Res. 2004, 57, 565-574. [CrossRef]

36. West, J.; Gallagher, S. Challenges of open innovation: The paradox of firm investment in open-source software. RED Manag. 2006, 36, 319-331. [CrossRef]

37. Hsu, C.W.; Lien, Y.C.; Chen, H. R\&D internationalization and innovation performance. Int. Bus. Rev. 2015, 24, 187-195.

38. DeAngelo, H.; DeAngelo, L.; Whited, T.M. Capital structure dynamics and transitory debt. J. Financ. Econ. 2011, 99, $235-261$. [CrossRef]

39. Globerman, S.; Shapiro, D. Global Foreign Direct Investment Flows: The Role of Governance Infrastructure. World Dev. 2002, 30, 1899-1919. [CrossRef]

40. Mansfield, E.D.; Pevehouse, J.C. Trade Blocks, Trade Flows, and International Conflict. Int. Organ. 2000, 54, 775-808. [CrossRef]

41. Pradhan, J.P. Emerging Multinationals: A Comparison of Chinese and Indian Outward Foreign Direct Investment. Inst. Econ. 2011, 3, 113-148.

42. Zahra, S.A.; George, G. Absorptive capacity: A review, reconceptualization, and extension. Acad. Manag. Rev. 2002, 27, 185-203. [CrossRef]

43. Harford, J. Corporate Cash Reserves and Acquisitions. J. Finance 1999, 54, 1969-1997. [CrossRef]

44. Nohria, N.; Gulati, R. Is slack good or bad for innovation. Acad. Manag. J. 1996, 39, 1245-1264. [CrossRef] 
45. Liu, Y.; Lin, W.-T.; Cheng, K.-Y. Family Ownership and the International Involvement of Taiwan's High-Technology Firms: The Moderating Effect of High-Discretion Organizational Slack. Manag. Organ. Rev. 2011, 7, 201-222. [CrossRef]

46. Smith, K.G.; Collins, C.J.; Clark, K.D. Existing Knowledge, Knowledge Creation Capability, and the Rate of New Product Introduction in High-Technology Firms. Acad. Manag. J. 2005, 48, 346-357. [CrossRef]

47. Cohen, W.M.; Levinthal, D.A. Absorptive capacity: A new perspective on learning and innovation. Adm. Sci. Q. 1990, 35, 128-152. [CrossRef]

48. Scott, J. Absorptive Capacity and the Efficiency of Research Partnerships. Technol. Anal. Strat. Manag. 2003, 15, 247-253. [CrossRef]

49. Romer, P.M. Endogenous Technological Change. J. Political Econ. 1990, 98, 71-102. [CrossRef]

50. Park, W.G. International Patent Protection:1960-2005. Res. Policy 2008, 37, 761-766. [CrossRef]

51. Amore, M.; Schneider, C.; Žaldokas, A. Credit supply and corporate innovation. J. Financ. Econ. 2013, 109, 835-855. [CrossRef]

52. Zhang, Y.; Tang, Y.H. Whether does trade liberalization promotes the productive efficiency of manufacturing enterprises. World Econ. 2013, 11, 51-71.

53. Foster, N. Intellectual property rights and the margins of international trade. J. Int. Trade Econ. Dev. 2012, 23, 1-30. [CrossRef]

54. James, M.; Thomas, F. Trade and direct investment in producer services and the domestic market for expertise. Can. J. Econ. 2005, $38,758-777$.

55. Zhong, X.J. Foreign direct investment in service industry and service structure upgrading: An empirical study. JinNan J. 2015, 2005, 155-163.

56. Ren, H.L.; Liu, H.H. A study on the impact of productive service trade on the international competitiveness of manufacturing industry: An empirical analysis based on China. Technol. Innov. Manag. 2010, 30, 323-326.

57. Hansen, B.E. Sample Splitting and Threshold Estimation. Econometrica 2000, 68, 575-603. [CrossRef]

58. Cohen, W.M.; Goto, A.; Nagata, A.; Nelson, R.; Walsh, J.P. R\&D Spillovers, Patents and the Incentives to Innovate in Japan and the United States. Res. Policy 2002, 31, 1349-1367.

59. Hall, B.; Helmers, C.; Rogers, M.; Sena, V. The Choice between Formal and Informal Intellectual Property: A Literature Review. J. Econ. Lit. 2015, 52, 375-423. [CrossRef]

60. De Leenheer, P.; Christiaens, S.; Meersman, R. Business semantics management: A case study for competency-centric HRM. Comput. Ind. 2010, 61, 760-775. [CrossRef]

61. Redding, S.; Venables, A. Economic geography and international inequality. J. Int. Econ. 2004, 62, 53-82. [CrossRef]

62. Yoo, Y.; Henfridsson, O.; Lyytinen, K. Research Commentary-The New Organizing Logic of Digital Innovation: An Agenda for Information Systems Research. Inf. Syst. Res. 2010, 21, 724-735. [CrossRef]

63. Teece, D.J. Profiting from innovation in the digital economy: Enabling technologies, standards, and licensing models in the wireless world. Res. Pol. 2018, 47, 1367-1387. [CrossRef]

64. Edwards, J.R.; Lambert, L.S. Methods for integrating moderation and mediation: A general analytical framework using moderated path analysis. Psychol. Methods 2007, 12, 1. [CrossRef]

65. Kurmanov, N.; Aliev, U.; Suleimenova, S. Analysis of the Efficiency of Innovation Management in the Countries of the Eurasian Economic Union. Pol. J. Manag. Stud. 2019, 19, 204-214. [CrossRef]

66. Imran, M.; Jian, Z.; ul Haque, A.; Urbański, M.; Nair, S.L.S. Determinants of firm's export performance in China's automobile industry. Sustainability 2018, 10, 4078. [CrossRef]

67. Azevedo, M.; Lobo, C.A.; Pereira, C.S.; Durão, N.; Maldonado, I. A possible relationship between internationalization and innovation strategies: An analysis of portuguese smes. Pol. J. Manag. Stud. 2021, 23, 74-90. [CrossRef] 